\title{
Thymus and autoimmunity
}

\author{
Alexander Marx ${ }^{1}$ (D) $\cdot$ Yosuke Yamada ${ }^{1,2} \cdot$ Katja Simon-Keller $^{1} \cdot$ Berthold Schalke $^{3} \cdot$ Nick Willcox $^{4}$. \\ Philipp Ströbel ${ }^{5} \cdot$ Cleo-Aron Weis $^{1}$
}

Received: 14 October 2020 / Accepted: 12 January 2021 / Published online: 3 February 2021

(C) The Author(s) 2021

\begin{abstract}
The thymus prevents autoimmune diseases through mechanisms that operate in the cortex and medulla, comprising positive and negative selection and the generation of regulatory T-cells (Tregs). Egress from the thymus through the perivascular space (PVS) to the blood is another possible checkpoint, as shown by some autoimmune/immunodeficiency syndromes. In polygenic autoimmune diseases, subtle thymic dysfunctions may compound genetic, hormonal and environmental cues. Here, we cover (a) tolerance-inducing cell types, whether thymic epithelial or tuft cells, or dendritic, B- or thymic myoid cells; (b) tolerance-inducing mechanisms and their failure in relation to thymic anatomic compartments, and with special emphasis on human monogenic and polygenic autoimmune diseases and the related thymic pathologies, if known; (c) polymorphisms and mutations of tolerancerelated genes with an impact on positive selection (e.g. the gene encoding the thymoproteasome-specific subunit, PSMB11), promiscuous gene expression (e.g. AIRE, PRKDC, FEZF2, CHD4), Treg development (e.g. SATB1, FOXP3), T-cell migration (e.g. TAGAP) and egress from the thymus (e.g. MTS1, CORO1A); (d) myasthenia gravis as the prototypic outcome of an inflamed or disordered neoplastic 'sick thymus'.
\end{abstract}

Keywords Thymus $\cdot$ Myasthenia gravis $\cdot$ Tuft cells $\cdot$ Myoid cells $\cdot$ AIRE $\cdot$ FEZF2

\section{Introduction}

The thymus generates responsive T-cells from immature precursors (together called 'thymocytes') as key players in a functional adaptive immune system. It also prevents human autoimmune diseases (HAIDs) through both negative

This article is a contribution to the special issue on: The thymus and autoimmunity - Guest Editor: Georg Holländer

Alexander Marx

Alexander.marx@umm.de

1 Institute of Pathology, University Medical Centre Mannheim, University of Heidelberg, Theodor-Kutzer-Ufer 1-3, 68167 Mannheim, Germany

2 Department of Diagnostic Pathology, Kyoto University Hospital, Kyoto 606-8507, Japan

3 Department of Neurology, Bezirkskrankenhaus, University of Regensburg, 93042 Regensburg, Germany

4 Neurosciences Group, Nuffield Department of Clinical Neurology, Weatherall Institute of Molecular Medicine, John Radcliffe Hospital, University of Oxford, Oxford, UK

5 Institute of Pathology, University Medical Center Göttingen, University of Göttigen, 37075 Göttingen, Germany selection (by which most autoreactive $\alpha / \beta$-T-cells are deleted $[1,2])$ and generation of FOXP $3^{+}$regulatory T-cells (Tregs) [3-6] that restrain those autoreactive T-cells that inevitably escape negative selection and seed the periphery [7,8]. Thymic tolerogenic mechanisms require thymic epithelial cells (TECs), dendritic cells (DCs) and B-cells and involve the cortex, medulla and perivascular spaces (PVS) (Fig. 1).

Monogenic HAIDs have been crucial to identifying key contributors to tolerance, e.g. the autoimmune polyendocrinopathycandidiasis-ectodermal dystrophy syndrome (APECED, alias autoimmune polyglandular syndrome type 1, APS1) due to autoimmune regulator (AIRE) mutations $[9,10]$, the immunodysregulation polyendocrinopathy and enteropathy Xlinked (IPEX) syndrome) resulting from FOXP3 mutations [11] and 'leaky' (subtotal) immunodeficiency syndromes due to primary T-cell or stromal cell developmental defects [12, 13]. Parallel studies in mouse models helped to elucidate underlying mechanisms and their non-redundancy $[6,14-16]$. In many sporadic polygenic HAIDs, the role of the thymus is difficult to prove, since disorders in tolerogenesis are often subtle and need complementary genetic, epigenetic, hormonal or environmental cues [17]. 'Primary' inflammatory and neoplastic disorders of the thymus in myasthenia gravis (MG) have highlighted thymic abnormalities that correlate with autoimmunity in humans [18]. 

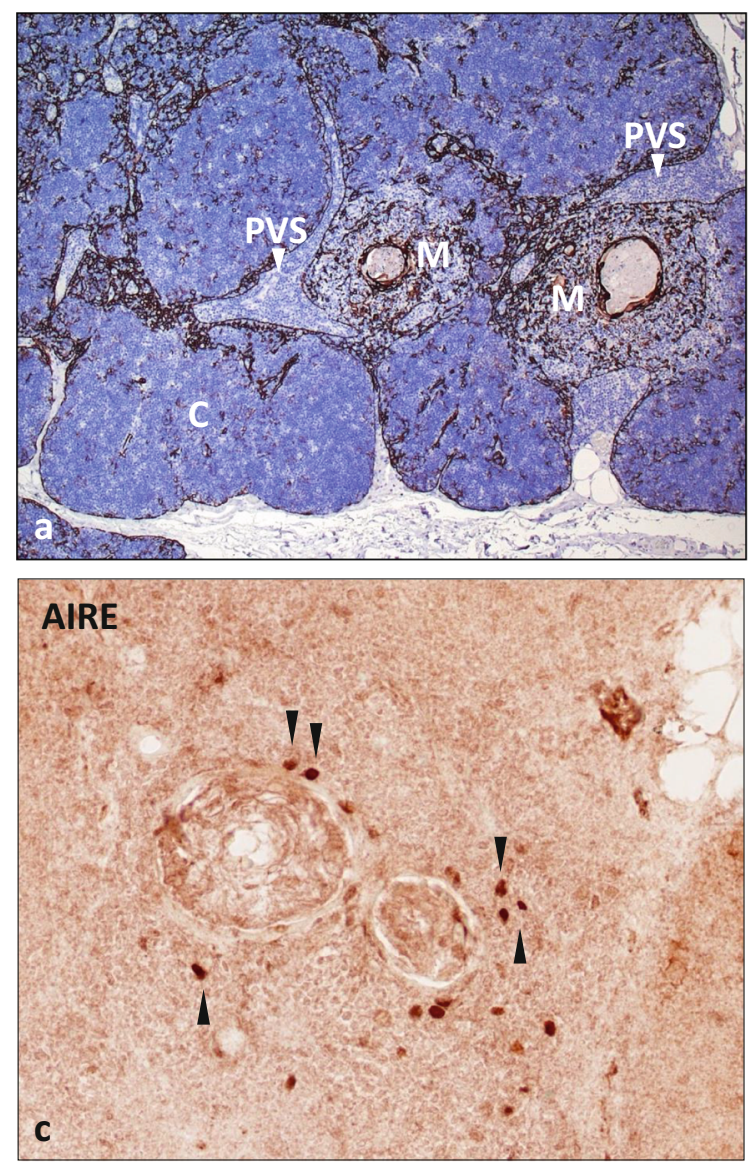

Fig. 1 Normal thymus. a Labelling of thymic epithelial cells with an antikeratin 19 antibody reveals three thymic compartments: cortex (C), medulla (M) and perivascular space (PVS, arrowheads). b Moderate content of $\mathrm{CD} 20^{+} \mathrm{B}$-cells around Hassall corpuscles (HC) in the medulla (M) of an adult thymus (40 years of age). c, d Nuclear AIRE

\section{The thymic medulla and autoimmunity}

\section{AIRE expression in the thymic medulla}

Identifying AIRE mutations as the cause of the APECED syndrome $[9,10]$ has deepened the understanding of negative selection. AIRE also supports the generation of antigenspecific natural Tregs in mice [15] and humans [19]. In humans, AIRE is expressed in the nuclei of rare mTECs mainly in the vicinity of Hassall corpuscles (Fig. 1). Since APECED thymic tissue is not available, AIRE's function has been elucidated through mouse models, although they do not fully mirror the clinical features of human APECED [20-22].

AIRE and negative selection AIRE is a transcriptional modulator that is mainly expressed in MHCII ${ }^{\text {high }}$ mTECs. Their development from $\mathrm{AIRE}^{--}, \mathrm{MHCII}^{\text {low }}$ precursors requires RANK/RANKL and CD40/CD40L signalling that, in turn, depends on thymopoiesis [23-25]; when it is deficient, thymic AIRE expression is therefore also missing, as in some primary
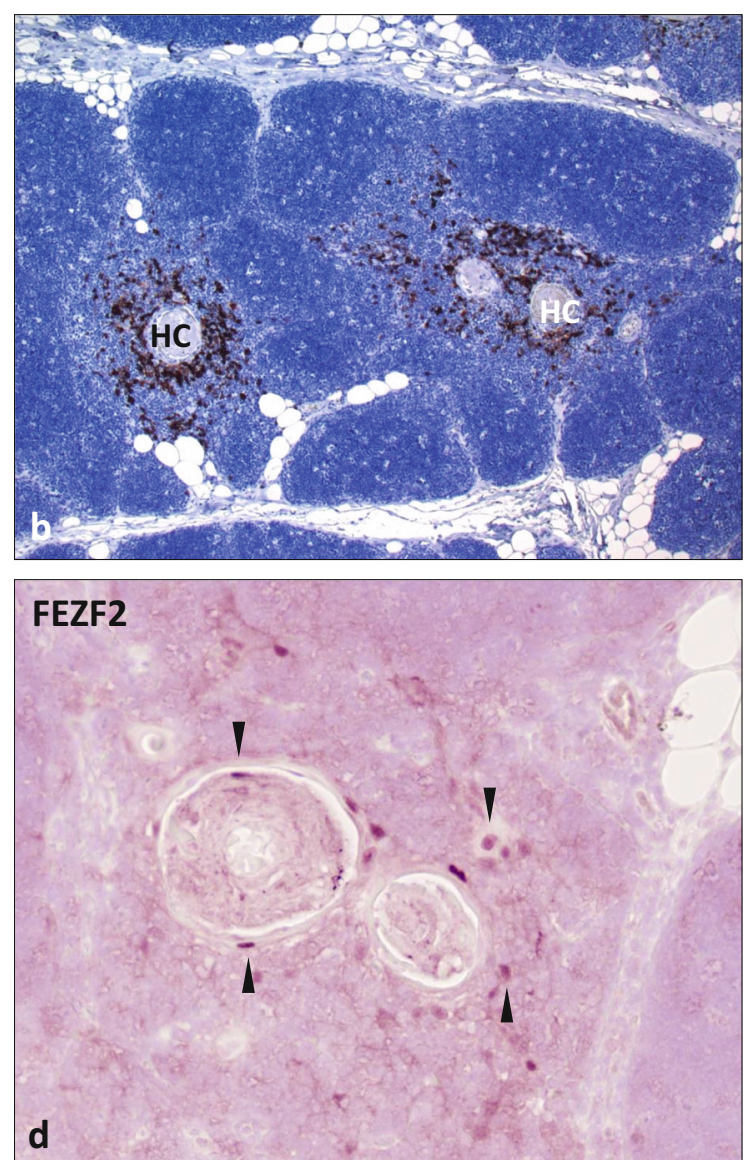

and FEZF2 expression in medullary thymic epithelial cells around two HCs (sequential staining of the same section). Many cells with AIRE/FEZF2 co-expression. Arrowheads highlight cells that stain exclusively for either AIRE or FEZF2. Immunoperoxidase

T-cell immunodeficiencies. In mTECs, AIRE is part of a multimeric complex including transcription factors, enhancers and DNA repair molecules [26] and drives the low-level 'promiscuous gene expression' (pGE) of more than 3000 tissuerestricted self-antigens (TRAs) [16], comprising about $40 \%$ of all TRAs expressed in the thymus [27]. Presentation of MHCbound, thymoproteasome-processed TRA-peptides [28] by mTECs deletes any maturing thymocytes with high affinities for these complexes $[14,16]$ or diverts them into the Treg lineage [29]. By contrast, cleavage in autophagic vacuoles is needed for peptide loading onto MHCII molecules [30], and blocking autophagy in mice elicits autoimmune colitis and multi-organ inflammation [31].

To achieve pGE, AIRE is preferentially recruited to promoters with low levels of $\mathrm{H} 3 \mathrm{~K} 4$ methylation [32]. It also induces topoisomerase II-dependent double-strand breaks, the editing and splicing of RNA [26, 33, 34]; promotes the release of stalled RNA polymerase-II [35] and enhances the binding of super-enhancers to 'orderly relaxed' chromatin [36, 37]. Furthermore, AIRE-dependent RNAs are preferentially stabilised through the $3^{\prime}$ end processing complex that 
generates short $3^{\prime}$ UTRs and protects against miRNAmediated degradation [38]. In the mouse, the spectrum of AIRE-driven TRAs is further broadened by cooperation of AIRE with the transcription factor, Fezf2, and the chromatin modulator, Chd4 [39]. On the other hand, the expression of AIRE and its target genes is suppressed by oestrogens, which may explain the gender bias of several autoimmune diseases [40].

Since any single AIRE-dependent TRA is stochastically expressed in only $1-3 \%$ of mTECs at a given time point [41, 42], thymocytes must be highly mobile to ensure sufficiently systematic screening throughout the thymic medulla for full tolerance induction [43]. Indeed, thymocyte motility defects can associate with autoimmunity [44].

Thymic DCs are also motile and can cross-present TRAderived $\mathrm{MHC} /$ peptide complexes, enhancing tolerance induction to TEC-derived TRAs [8, 45-47], especially any derived from AIRE-independent TRAs [48].

AIRE expression in cells other than mTECs: AIRE is also expressed at lower levels in minority subsets of (i) murine and human thymic B-cells [49-52], (ii) $\mathrm{CCR} 7^{+} \mathrm{PDL}^{--} \mathrm{CD} 127^{+}$ medullary thymic DCs $[53,54]$ and (iii) rare extrathymic DCs [55]. While B-cells and DCs are important for tolerance induction, the relevance of AIRE expression in a few of each is less clear: it might even be linked to the maturation of thymic and peripheral DCs [53].

AIRE and Treg development AIRE is involved in the positive selection of a subset of self-antigen-specific Tregs, whether directly through $\mathrm{AIRE}^{+}$mTECs [15] or indirectly by their transfer of MHCII/TRA peptide complexes to $\mathrm{AIRE}^{--}$DCs [56], using different molecular transfer mechanisms for cell surface and cytosolic proteins [47]. It is unknown why some AIRE-dependent TRAs preferentially induce Treg development [29, 57], whereas others induce deletion [58].

Human AIRE-related autoimmune features Patients with inactivating AIRE mutations develop APECED due to autoimmune $\mathrm{T}$ - and B-cell responses that damage many organs, preferentially the adrenal cortex and parathyroid glands [20]. In contrast to AIRE-deficient mice [21], nearly all APECED patients show neutralizing autoantibodies to type I interferons and TH17 interleukins [59-61], and loss of Th17 and Th22 cells [62], which correlate with the characteristic mucocutaneous candidiasis, which is often the first sign of APECED [62, 63]. Their autoantibodies to Th17-directed cytokines interfere with macrophage activation, whereas others (e.g. against IL22) reportedly protect against type 1 diabetes (T1D) [64]. APECED patients also variably share autoantibodies with other HAIDs, including cancer tissue antigens [65], suggesting a role of the thymus in anti-tumour immunity $[66,67]$.

AIRE polymorphisms have been associated with sporadic vitiligo [68] and rheumatoid arthritis (RA) [69] but not with other common autoimmune diseases such as T1D [70]. Mutations of genes that encode 'AIRE partners' (e.g. mutations of $P R K D C$ [71]) can cause APECED-like syndromes.

Pathology The features of thymi in APECED patients are unknown. AIRE expression deficits in humans occur in thymomas (see below) and primary immunodeficiencies.

\section{FEZF2 and CHD4 expression in mTECs}

The second gene identified to drive TRA expression in the thymus is the transcription factor 'forebrain expressed zinc finger 2' (Fezf2) [72]. It is mainly expressed in the brain [73, 74], also close to Hassall corpuscles in the human thymus, and in a subset of mTECs, some being AIRE $^{+}$too [39] (Fig. 1). Fezf2 regulates the expression of about 400 TRAs that are distinct from those regulated by AIRE [34]. About 1000 TRAs are co-regulated by either Fezf2 and AIRE [34] or Fezf2 and Chd4 [39]. Transplantation of Fezf2 ${ }^{-/}$thymi into nude mice elicits organ infiltrates and autoantibodies that are different from those in $\mathrm{AIRE}^{-/-}$mice $[14,72]$.

Recently, chromodomain helicase DNA-binding protein 4 (Chd4) was identified as the first Fezf2-interacting protein [39]. It is a broadly expressed chromatin modulator that elicits histone modifications of its target genes distinct from those in AIRE-induced genes [39]. Chd4 and Fezf2 cooperatively regulate the expression of more than $25 \%$ of Fezf2-dependent genes by modifying the chromatin state around them, while Chd4's co-regulation of 30\% of AIRE-dependent genes [39] involves super-enhancers [34]. In mice, Chd4 induces the expression of a small set of unique genes [39].

Human FEZF2 and CHD4-related autoimmune features As yet, there is no genetic or pathologic evidence directly to incriminate FEZF2 or CHD4 in either sporadic HAIDs or syndromes analogous to APECED. However, some Fezf2dependent TRAs identified in mice are autoantigens in humans, including aquaporin 8 (AQP8) in Sjögren syndrome [75] and transthyretin (TTR) in juvenile idiopathic arthritis (JIA) [76]. Some of the Chd4-(co-)regulated genes in mice encode human autoantigens, including TSHR, the key autoantigen in Graves' disease [77, 78].

\section{Other autoimmune risk polymorphisms involving mTECs}

Some risk polymorphisms for sporadic HAIDs operate in the thymus, e.g. those in the AIRE-driven INS/insulin promoter that associate with insulin expression levels in the thymus rather than the pancreatic islets and, inversely, with the risk of developing T1D [79, 80] even among APECED patients [81]. Similarly, a polymorphism in the IRF8-binding site in the promoter of the AIRE-driven gene encoding the 
acetylcholine receptor (AChR) $\alpha$-subunit has been linked to reduced $\mathrm{AChR}$ expression in the thymus and the risk of very early-onset myasthenia gravis [82]. Analogous scenarios apply to Graves' disease [77], autoimmune myocarditis [83] and central nervous system autoimmunity (see A. Handel, this fascicle).

\section{Hassall corpuscles, thymic tuft cells, thymic myoid cells and autoimmunity}

Like thymic tuft cells, the squamoid cells that constitute Hassall corpuscles (HCs) in the human medulla (Fig. 1) and inconspicuous aggregates in the murine thymus [84] are terminally differentiated mTECs [85-87]. Thymic myoid cells are rare skeletal muscle-like cells occurring close to HCs [88].

Hassall corpuscles arise from $\mathrm{AIRE}^{+} \mathrm{MHCII}^{\text {high }}$ mTECs under the influence of thymocyte-dependent lymphotoxin signals [87]. Terminal mTEC differentiation is accompanied by downregulation of AIRE, MHCII and CD80/CD86 and upregulation, e.g. of KRT10, involucrin, desmogleins and serine protease inhibitor (SPINK5), characteristic of terminally mature cutaneous keratinocytes [34, 86]. Despite the downregulation of AIRE, squamoid mTECs still express many AIREdependent and independent TRAs before dying inside HCs [48]. HCs supposedly promote tolerance in two ways: through transfer of TRAs to nearby DCs for cross-presentation [34] and through secretion of thymic stromal lymphopoietin (TSLP) that induces CD80/CD86 on $\mathrm{MHCII}^{+}$DCs that, in turn, promotes Treg development in the presence of IL-2 $[89,90]$. The TSLP pathway may not operate in mice, whose squamoid mTECs lack TSLP expression [85].

Thymic tuft cells (TTCs) in mice likely represent the rare microvillous mTECs [91]. They arise from AIRE ${ }^{+}$and $\mathrm{AIRE}^{-}$ mTECs $[85,86]$ and partially resemble the chemosensory tuft ('brush') cells that were first identified in mucosal tissues [92, 93] and meanwhile in many other organs [94]. Like other tuft cells but unlike other TECs, TTCs develop under the control of the transcription factor, POU2F3, and express many tuft cell markers, including IL-25, the protein kinase DCLK1, pro-inflammatory cyclooxygenases [95], proteins involved in acetylcholine metabolism (e.g. ChAT) and taste transduction (e.g. Trpm5); yet, they do not show pGE $[85,86]$. On the other hand, TTCs specifically express MHCII and CD74 that are involved in antigen presentation; they also induce tolerance against IL-25 that is lost in TTC-deficient mice [86], though its breadth and mechanisms are currently unknown.

Thymic myoid cells (TMCs) are evolutionarily conserved, non-innervated mesenchymal cells that resemble myoblasts or myotubes [88] and occur in the normal medulla (i.e. near HCs, $\mathrm{AIRE}^{+}$and $\mathrm{FEZF}^{+}$mTECs, POU2F3 ${ }^{+}$thymic tuft cells and thymic B, T and DCs). Their origins [96, 97] and kinship to mTECs with a 'myoid phenotype' [54] are unclear. In contrast to mTECs, TMCs express AChR in its native confirmation [98] that is exclusively recognised by MG patients' autoantibodies: indeed, they are the only cells outside the muscle to express this key target autoantigen, as well as titin [99] and ryanodine receptors (RyRs) [100]. Since TMCs are $\mathrm{MHCII}^{--}$ [98], they may contribute to tolerance through transfer of muscle self-antigens to DCs for cross-presentation to T-cells [18]. So may isolated AChR subunits or other muscle proteins that are also expressed by mTECs [54, 98, 101], suggesting that immune tolerance to skeletal muscle has been a high priority during evolution.

Human autoimmune features related to HCs, TTCs and TMCs Impaired TEC/thymocyte crosstalk leads to lack of $\mathrm{AIRE}^{+}$ mTECs and of the HCs that they generate, possibly increasing risks of HAIDs: many primary T-cell immunodeficiency syndromes, e.g. hypomorphic defects of RAG-1, and some inborn errors of thymic stroma development result in lymphocytepoor, $\mathrm{AIRE}^{--}$and $\mathrm{HC}$-deficient thymic rudiments ('thymic dysplasia') and may associate with HAIDs (see R. Bachetta and F. Dhalla in this fascicle). So does trisomy 21, with three AIRE alleles, enlarged HCs and increased risks of T1D, but the mechanisms involved are controversial [102-104]. The decline of $\mathrm{HC}$ numbers during aging [105] results from a decline of haematopoietic and epithelial cell functions [106] and may contribute to the increased prevalence of some HAIDs in the elderly [107]. Thymic tuft cell deficiency has not been reported in humans. Combined deficiencies of TMCs, HCs and AIRE expression in thymomas are detailed below.

\section{Hematopoietic cells in the thymic medulla and autoimmunity}

Thymic dendritic cells are classified as $\mathrm{CD} 8 \alpha^{+} \operatorname{Sirp} \alpha^{--}$conventional DCs ( $\mathrm{cDC} 1 \mathrm{~s}$ in mice and $\mathrm{CD} 141^{+} \mathrm{cDCs}$ in humans), CD $8 \alpha^{--}$Sirp $\alpha^{+}$DCs (cDC2s, including a monocyte-derived $\mathrm{CD} 4^{+}$DC subset [108]) and plasmacytoid DCs (pDCs) [108-110]. cDC1s are generated intrathymically from immature precursors recruited to the thymus by mTEC-derived CCL21s [111], while other DCs are attracted from the periphery as mature cells $[112,113]$ by mTEC-derived chemokines, some of which require toll-like receptor 9 (TLR9)/MYD-88 signalling for production [108]. AIRE-dependent mTECs secrete XCL1 [114] that attracts cDCs and facilitates their acquisition of promiscuously expressed antigens from mTECs [45-47, 115], while pDCs essentially present peripheral antigens [113]. Antigen transfer from mTECs to DCs is key for the cross-presentation of promiscuously expressed antigens for negative selection $[8,45,115]$ and the generation of Tregs $[47,114,116]$. Compared with mTECs and medullary 
B-cells, DCs show the highest expression levels of HLA genes but low levels of TRA genes [50,53].

Thymic B-cells occur in the medulla from foetal life onwards [117]. Their abundance increases with age. Thymic $\mathrm{AIRE}^{+}$and $\mathrm{AIRE}^{--} \mathrm{B}$-cells play a role in deletional tolerance: following activation through autoreactive T-cells and CD40 signalling, B-cells express AIRE together with a set of TRAs and present MHCII/TRA-peptide complexes, and so specifically delete the autoreactive T-cells that activated them [52, 118]. In humans, $5 \%$ of thymic B-cells express AIRE [49, 50, 119]. Since their set of AIRE-dependent TRAs is different from that in mTECs, thymic B-cells may delete T-cells with distinct self-reactive specificities $[49,50,119]$ or help to divert them into the Treg lineage [120-122].

Regulatory T-cells A minority of developing $\mathrm{CD}^{+} \mathrm{T}$ cells with $\alpha / \beta$-T-cell receptors (TCR) develops towards the Treg lineage if recognizing self-peptide/MHCII complexes with intermediate affinities [123]. Thus, the TCR repertoire of thymus-derived Tregs (tTregs) is skewed towards recognizing self-antigens compared with conventional $\mathrm{CD}^{+}$helper $\mathrm{T}$ cells (TH-cells) [124]. Tregs constitute about $10 \%$ of all $\mathrm{CD}^{+} \mathrm{T}$-cells, of which $80-90 \%$ are tTregs; peripheral Tregs (pTregs) arise from mature, conventional $\mathrm{CD}^{+} \mathrm{T}$-cells [125]. The development of tTregs starts in the cortex: in the presence of TCR and IL-2/STAT3 signalling, the transcription factor, SATB1, binds to closed DNA regions in cortical $\mathrm{CD} 4^{+} \mathrm{CD} 8^{+}$ thymocytes to initiate chromatin opening. A defect at this level elicits Treg deficiency and autoimmunity [126]. Subsequently, $\mathrm{CD} 4^{+} \mathrm{CD} 8^{--}$single positive thymocytes develop in the medulla through further epigenetic modifications, establishment of the 'Treg-specific demethylated region, TSDR' [127] and binding of transcription factors (e.g. RUNX1, CBFFB, ETS1, FOXO1 and 3) that drive expression of CD25, FOXP3, CTLA4 and other 'Treg signature genes' [128]. Cues from Hassall corpuscle-instructed medullary DCs [89] and AIRE $^{+}$mTECs $[15,19]$ in the presence of MHCII, CD80/86 and IL-2 [90] control the abundance, antigenspecificity and suppressive competence of these tTregs. Once expressed, FOXP3 maintains survival and function of Tregs through driving target gene expression (e.g. of $C D 25$ / IL2RA and CTLA4) or suppression of pro-inflammatory IL2 and $I F N G$ ) [123]. Recently, two developmental pathways leading to tTregs with distinct target specificities were described [129] and may be present in the human thymus [54].

\section{Human autoimmune features related to hematopoietic cells} Thymic DC numbers do not change much during ageing [130], but proinflammatory genes (e.g. $L I F, I L O)$ are increasingly expressed and may contribute to involution [131, 132], though with no proven link to HAIDs.

In B-cells, the declining transcription with age of $A I R E$ and rare TRA genes, including TTN (encoding the muscle protein, titin), has been linked to the commoner occurrence of some HAIDs including MG in the elderly [49, 107].

Severe defects of Tregs occur in monogenic autoimmune diseases. For example, IPEX syndrome (analogous to murine scurfy syndrome [3]) results from different mutations across the FOXP3 gene [133], showing that Tregs are indispensable to prevent T1D (even perinatally), inflammatory bowel disease and allergies, although the clinical variability of IPEX correlates poorly with the type of FOXP3 mutation [134]. Other mutations in CD25, CTLA4, LRBA, BACH2 and STAT3 cause 'IPEX-like syndromes' due to Treg dysfunction. Differences in their expression, e.g. in follicular TH- and B-cells, may contribute to clinical differences between these 'Tregopathies' [135] (see R. Bacchetta in this fascicle). In addition, genetic variants in Treg-related loci associate with some common sporadic autoimmune diseases [128, 136].

Pathology The thymus in an IPEX patient showed dysplasia, i.e. lack of lymphoid cells and Hassall corpuscles [137]. These changes are likely secondary, resembling those in scurfy mice, where severe thymic atrophy likely results from the cytokine storm and lymphoproliferation that develop in the absence of Tregs [138].

\section{The thymic cortex and autoimmunity}

The thymic cortex provides the microenvironment for positive selection of conventional T-cells and early Tregs. Thus, its cTECs generate distinctive self-peptides via a unique set of proteases: (a) to select $\mathrm{CD} 8^{+}$thymocytes, cytosolic peptides are generated for presentation on MHCI molecules by the cortex-restricted 'thymoproteasome', with its unique Beta5t subunit (encoded by PSMB11) [28]; (b) to select $\mathrm{CD}^{+}$thymocytes, MHCII molecules in cTECs are loaded inside LAMP $2^{+}$endosomes with various endogenous selfpeptides generated using cathepsin $\mathrm{L}$ and the thymusspecific serine protease, TSSP (encoded by CTSL and PRSS16, respectively) [139]. Autophagy in cTECs is one source of such MHCII:peptide complexes [30]; they also owe their persistence on the cTEC surface to CD83dependent blockade of MACH-8-mediated trafficking there $[140,141]$. This positive selection clearly depends on some crucial survival signals for nascent T-cells delivered via their TCRs, available co-receptors and downstream molecules (such as the tyrosine kinase, ZAP70) that transmit TCR signals [142-144]. Once positively selected, thymocytes upregulate chemokine receptors (e.g. CCR7) and must migrate to the medulla along chemotactic gradients $[145,146]$ for proper establishment of central tolerance [147]. 
Human autoimmune features related to thymic cortical dysfunction Homozygosity for the rs54457782 SNP of PSMB11 has been associated with altered B5t function of the protein in cTECs and an elevated risk of Sjögren syndrome in one study [148].

Deletion of Prss 16 in cTECs clearly protects NOD mice against T1D, presumably by affecting processing of pancreatic islet cell TRAs [149]. A role of PRSS16 in HAIDs has not been proven.

Polymorphisms of the C-type lectin CLEC16A gene show associations with T1D, multiple sclerosis (MS), systemic lupus (SLE), celiac disease, RA and JIA. Mouse studies implicate CLECA16's impact on autophagy in cTECs or mTECs and thus on the repertoire of $\mathrm{MHCII} /$ self-peptide complexes for $\mathrm{CD}^{+}{ }^{+} \mathrm{T}$-cell selection [150].

In a similar scenario, 'autoimmunizing positive selection' (complemented by defective negative selection) might be operative in thymomas (see below), and in patients with ZAP70 mutations: while inactivating mutations of ZAP70 cause severe immunodeficiency, hypomorphic mutations lead to positive selection of autoreactive thymocytes [142]. Since attenuated ZAP70 signalling also attenuates negative selection and selection of Tregs, autoimmunity arises [151], leading to bullous pemphigoid, colitis and proteinuria in patients [152].

Nucleotide variants of TAGAP that encode a thymocyte GAP protein are associated with various HAIDs, likely reflecting attenuated thymocyte migration from the cortex to the medulla [44].

Finally, associations of SNPS of SATB1 with colitis, psoriasis and MS have been linked to SATB1's role in Treg development in the thymic cortex [126].

Pathology Expansion of the thymic cortex at the near-total expense of medullary regions is typical of thymomas (see below). Conversely, secondary cortical atrophy can result from the chronic re-entry of activated peripheral T-cells into the thymus in HAIDs [153]. Cortical atrophy as a facet of thymic involution during aging is thought to increase the risk of HAIDs [154].

\section{PVS and autoimmunity}

The third thymic compartment with relevance for autoimmunity is the epithelial-free perivascular space (PVS) (Fig. 1). It surrounds vessels that enter the thymus through the septa between cortical lobules up to the corticomedullary junction (CMJ) [155]. The PVS extends between the basal membranes of the outermost epithelial cells of thymic lobes to those of the intrathymic vessels. Barely visible in infants, these PVS enlarge with age [156]. At the CMJ, they are the entry sites for both immature lymphoid progenitors and recirculating T-, Band dendritic cells from the blood and for exit for mature $\mathrm{T}$ - cells to the blood [145, 157, 158]. Furthermore, they are niches for B-cells and plasma cells spontaneously secreting protective antibodies that also prevent tolerance to viruses in healthy subjects [159], as in mice [160], or secrete pathogenic antibodies in early-onset myasthenia gravis (EOMG; see below).

Successfully selected CD69 $9^{\text {low }}$ nascent T-cells emigrate from the medulla to the PVS to the blood. That depends partly on cytokines, chemokines and integrins, also on (a) the sphingosine-1-phosphate (S1P) gradient between the S1P low medulla and the S1P $\mathrm{P}^{\text {high }}$ blood [43], the balance between S1Pproduction by pericytes in the PVS and degradation by stromal cells (mostly DCs) in the medulla in mice [157, 161-164] and humans [165], and (b) the corresponding upregulation of $\mathrm{S} 1 \mathrm{P}$ receptors $\left(\mathrm{S} 1 \mathrm{PR}_{1}\right)$ on the nascent $\mathrm{T}$-cells; (c) signals from endothelial cells to pre-emigrant T-cells [166], and T-cell intrinsic factors like the protein kinase MTS1 (a member of the Hippo pathway) and the actin regulator, Coronin-1A (encoded by $C O R O 1 A$ ) that regulate $\mathrm{T}$-cell polarisation, adhesion and migration [157].

B-cells in PVS accumulate progressively with age and switch from a mainly $\operatorname{IgM}^{+} \mathrm{IgD}^{+} \mathrm{CD} 27^{--}$naïve phenotype in infants to a class-switched $\operatorname{IgG} 1 / \operatorname{IgG} 3 / \mathrm{IgA}^{+} \mathrm{CD} 27^{+}$memory phenotype in adults [159].

\section{Human autoimmune diseases related to T-cell migration and} the PVS Defects of thymocyte adhesion, migration and egress from the thymus are typically associated with a combined (T-/Bcell) immunodeficiency, as exemplified by mutations of MST1 [167-169] and CORO1A [163]. Poor adhesion and migration that compromise interactions between thymocytes and antigenpresenting cells attenuate positive and negative selection and the development and function of Tregs [43, 169, 170]. In MTS1 mutant thymi, some T-cells typically escape to the periphery, where rarely oligoclonal or even monoclonal lymphoproliferations, organ infiltrates and autoantibody-mediated cytopenias develop [168, 171]. In CORO1A mutations, the egress defect is generally so severe that autoimmunity is generally prevented.

Pathology Thymi with defects in egress due to mutations of MTS1 and CORA1A usually retain their corticomedullary architecture [163]. The generally mild defect in MTS1 mutations shifts the balance towards a higher proportion of mature thymocytes, while the massive block to egress in CORO1A mutated thymi leads to 'giant PVS' with accumulations of mature T-cells [172].

\section{Autoimmune myasthenia gravis-the inflamed and neoplastic thymus}

Myasthenia gravis $(\mathrm{MG})$ is a $\mathrm{CD} 4^{+} \mathrm{T}-$-cell-dependent HAID, where autoantibodies interfere with neuromuscular transmission, causing muscle weakness. Autoantibodies in $80 \%$ bind 
to the AChR [173]. This 'AChR-MG group' comprises EOMG (onset before age 50), late-onset MG (LOMG; onset age $>50$ ) and thymoma-associated MG (TAMG) that show inflammatory, atrophic and neoplastic thymic alterations, respectively, with distinct clinical and genetic associations (Table 1). Here, we focus an EOMG and TAMG, since patients with LOMG appear heterogeneous, pathogenesis is largely unclear $[175,180,181]$, and MG types due to other autoantibodies have an uncertain thymic phenotype [182-184].

\section{Thymic inflammation and immunopathogenesis of early-onset MG}

The hallmark of EOMG is thymic follicular hyperplasia (TFH), i.e. ectopic lymphoid follicles in PVSs merging with the thymic medulla [185] (Fig. 2). TFH shows germinal centres and increased numbers of B-cells and plasma cells and correlates with intrathymic production of heterogeneous $\operatorname{IgG}$ autoantibodies with high affinities for native AChR. Female gender and the HLA-DR3 B8 A1 haplotype are strong risk factors [186], B8 appearing the strongest [177], though roles of other loci are less clear (Table 1). EOMG is highly heritable [179] and commonly associated with other AIDs, predominantly thyroiditis, SLE and RA $[184,186]$. The triggers of TFH are unknown [187]. A type I interferon signature in the inflamed thymus hinted at viral infections [188], but no specific pathogen could be linked to MG [187]. Still, there are strong arguments for intrathymic initiation of TFH $[189,190]$ : (1) anti-AChR autoantibodies are preferentially produced in the EOMG thymus [191] by terminal plasma cells [192]; (2) in many patients, they preferentially recognise foetal AChRs [193] that are almost exclusively expressed on thymic myoid cells (TMCs); (3) TMCs are attacked by autoantibodies and complement in EOMG $[182,190]$ and closely associate with DCs that supposedly cross-present TMC-derived AChRpeptides to autoreactive T-cells for subsequent stimulation of autoreactive B-cells [194]; (4) lymphoid follicles disrupt the normally continuous basal membrane and epithelial cell layer around PVS, displacing TMCs from the tolerogenic medullary parenchyma into the inflamed vicinity of lymphoid follicles, many of which harbour AChR-autoreactive B-lineage cells in germinal centres [192, 195]; (5) in EOMG, mTECs that express unfolded AChR subunits [101] are attacked by complement and anti-epithelial autoantibodies of unknown specificity $[196,197]$ and over-express CXCL13 that recruits peripheral B-cells to the thymus [198]. Together with the beneficial effect of thymectomy [199], these findings support the 'intrathymic pathogenesis concept' of EOMG [189, 200]. Based on these observations, the finding of AChR-autoreactive, $\mathrm{CD}^{+}$effector T-cells in the repertoire of almost everybody [201,202] and the fact that mature human T-cells recirculate to the thymus [203] currently favour a 2-step intrathymic pathogenesis model of EOMG [190] (Fig. 3):

Step 1: AChR-reactive T-cells are primed (for unknown reasons) by mTECs that express MHC/AChR-peptide complexes, and then elicit low-affinity antibodies against linear AChR epitopes.

Step 2: These 'early antibodies' attack $\mathrm{AChR}^{+} \mathrm{TMCs}$, activate complement and cause the release of $\mathrm{AChR} / \mathrm{immune}$ complexes that, in turn, activate DCs to initiate ectopic follicle and germinal centre formation and focus the autoantibody response onto AChR rather than other muscle targets [190]. It is unknown whether follicles develop primarily near TMCs in the medulla and subsequently in B-cell niches in PVS [159] or vice versa. In either case, a very similar scenario has since been proposed for the development of thymic B-cell follicles in type 1 diabetes-prone NOD mice, including the attack of

Table 1 Features and risk factors of myasthenia gravis (MG) subtypes with anti-acetylcholine receptor (AChR) autoantibodies, comprising early-onset MG (EOMG), late-onset MG (LOMG) and thymoma-

associated MG (TAMG) [82, 174-180]. Onset-ages may be subject to revision. EOMG and LOMG may prove to overlap, and the cut-off age(s) to differ between the sexes

\begin{tabular}{|c|c|c|c|c|c|c|c|}
\hline $\begin{array}{l}\text { MG } \\
\text { type }\end{array}$ & Autoantigen targets & $\begin{array}{l}\text { Onset-age } \\
\text { (years) }\end{array}$ & $\mathrm{M}: \mathrm{F}$ ratio & Genetic risk factors in Caucasians & Thymic pathology & $\begin{array}{l}\mathrm{AIRE}^{+} \\
\text {mTECs }\end{array}$ & $\begin{array}{r}\text { Myoid } \\
\text { cells }\end{array}$ \\
\hline EOMG & $\mathrm{AChR}$ & $<50-60$ & $1: 3$ & $\begin{array}{l}\text { MHC class I }>I^{\mathrm{a}}\left(C H R N A 1^{\mathrm{b}}\right) P T P N 22 \\
\quad\left(C T L A 4^{l o w}\right)(T N I P 1)\end{array}$ & $\begin{array}{l}\text { Ectopic germinal } \\
\text { centres }\end{array}$ & $\begin{array}{l}\text { Normal } \\
\text { number }\end{array}$ & $\begin{array}{l}\text { Normal } \\
\text { number }\end{array}$ \\
\hline LOMG & $\begin{array}{l}\mathrm{AChR} \pm \text { titin } \\
\text { cytokines RYR } 1 / 2\end{array}$ & $>50-60$ & $2: 1$ & $\begin{array}{l}\text { MHC class II }>\mathrm{I}^{\mathrm{a}} \text { TNFRS11A (PTPN22) } \\
\quad\left(C T L A 4^{\text {low }}\right.\end{array}$ & Atrophy & Reduced & Reduced \\
\hline TAMG & $\begin{array}{l}\mathrm{AChR} \pm \text { titin } \\
\text { cytokines RYR } 1 / 2\end{array}$ & $\begin{array}{l}\text { Any (median } \\
\text { age } \sim 50)\end{array}$ & $1: 1$ & $\begin{array}{l}\text { None } \\
\text { established }\left(C T L A 4^{h i g h}\right)\end{array}$ & $\begin{array}{l}\text { Thymic epithelial } \\
\text { neoplasm }\end{array}$ & Absent & Absent \\
\hline
\end{tabular}

CHRNA1 AChR a-subunit gene [82], PTPN22 protein tyrosine phosphatase, non-receptor-type, 22, CTLA4 cytotoxic T lymphocyte-associated 4: the unique CTLA4 high-expresser risk genotype in TAMG suggests a role of CTLA4 in central tolerance failure [176], TNIP1 TNFAIP3-interactin protein 1, TNFRS11A TNF receptor superfamily, member 11A (RANK), RYR1/2 ryanodine receptors 1 and 2

${ }^{a}$ Associations awaiting confirmation $[174-177,179,180]$ are given in brackets; the HLA-DQA $1 * 05: 1$ gene is predisposing in EOMG and protective in LOMG $[177,180]$

${ }^{\mathrm{b}}$ Cytokines (type I interferons; IL12) 

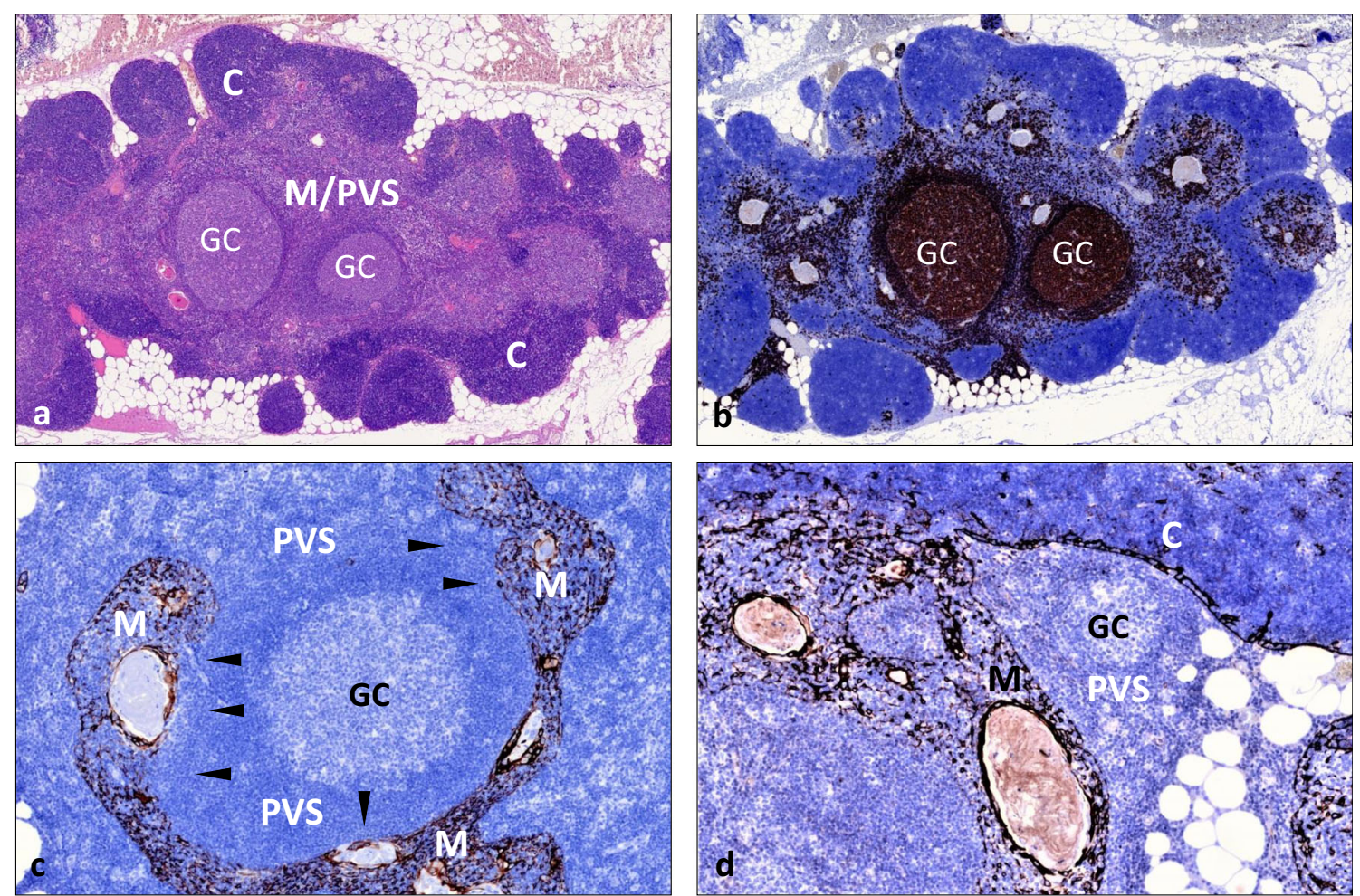

Fig. 2 Thymus with 'thymic lymphoid follicular hyperplasia' (TFH) in early-onset myasthenia gravis (EOMG). a Hematoxylin-eosin stain showing well delineated dark staining cortical areas (C) and extended, light-staining areas with a merger of medulla and perivascular space (PVS) including two lymphoid follicles with germinal centres (GC). b CD20 stain highlights massive increase of B-cells. c Keratin 19 stain

anti-epithelial autoantibodies on autoantigen (insulin)-expressing mTECs, activation of autoreactive T-cells and accumulation of B-cells [204].

TFH responses might be self-perpetuating in EOMG if (i) AChR persists on TMCs that are damaged by complement but do not disappear [205]; (ii) Tregs are functionally compromised [206, 207]; and (iii) TLR-expressing antigen-presenting cells are abnormally active [208]. Finally, autoreactive T- and B-cells spread to the periphery [209], where, hypothetically, the flow of skeletal muscle-derived AChR/antibody-complexes to regional lymph nodes and functionally impaired Tregs perpetuate EOMG even after thymectomy [184, 199].

\section{Thymoma and the immunopathogenesis of TAMG}

Thymomas are thymic epithelial tumours with variably mixed cortical and medullary differentiation accompanied by thymopoiesis in $>90 \%$ of patients [210, 211]. TAMG is the single most common thymoma-associated HAID (30-40\%), while others (e.g. thyroiditis, RA, and especially SLE, pure red cell aplasia (PRCA), hypogammaglobulinaemia or other bone marrow failures are individually less common (each 1$5 \%$ ) but, together with TAMG, amount to over $50 \%$ thymoma-associated HAIDs [18]. Most of the HAIDs are

highlights keratin 19(+) medullary areas (M) compared with a massively enlarged, epithelial-free perivascular space (PVS) with a large lymphoid follicle with germinal centre (GC); interrupted epithelial layer between PVS and medulla (arrowheads). d Small lymphoid follicle restricted to the slightly expanded PVS with intact continuous epithelial layer between PVS, medulla (M) and cortex (C). Immunoperoxidase

$\mathrm{CD}^{+} \mathrm{T}$-cell-dependent, autoantibody-mediated (e.g. TAMG), while cytotoxicity may be operative in others (e.g. in PRCA) $[212,213]$. Unlike in EOMG, $>80 \%$ of patients with thymomas have autoantibodies to non-AChR skeletal muscle antigens (titin and RYRs) and others that neutralise such cytokines as type I interferons $(\sim 70 \%[22,61,62]$ and IL-12) (Table 1). Those against the muscle have been attributed to the lack of thymic myoid cells (TMCs) in thymomas [18] and/or expression of AChR, titin and RYR epitopes in neoplastic thymic epithelial cells [100, 214].

The autoantibodies against type I interferons (all 12 subtypes [190]) are among several striking parallels with $>90 \%$ of APECED patients: others include the chronic mucocutaneous candidiasis (CMC) that is often the first sign of APECED, also occurs in $\sim 3 \%$ of thymoma patients and has an autoimmune basis in both-i.e. autoantibodies against IL-17s and/ or IL-22 and loss of the cytokine-producing cells [62]. The apparent absence of AIRE in most thymomas [215] renders these tumours the most practical alternative for studying AIREdeficient thymopoiesis in humans $[22,216]$. The differences between these syndromes include the rarity in APECED patients of MG or of almost any neurological disorder or autoantibody [22]; they may partly reflect the contrasting effects of AIRE mutations present since conception in APECED versus 


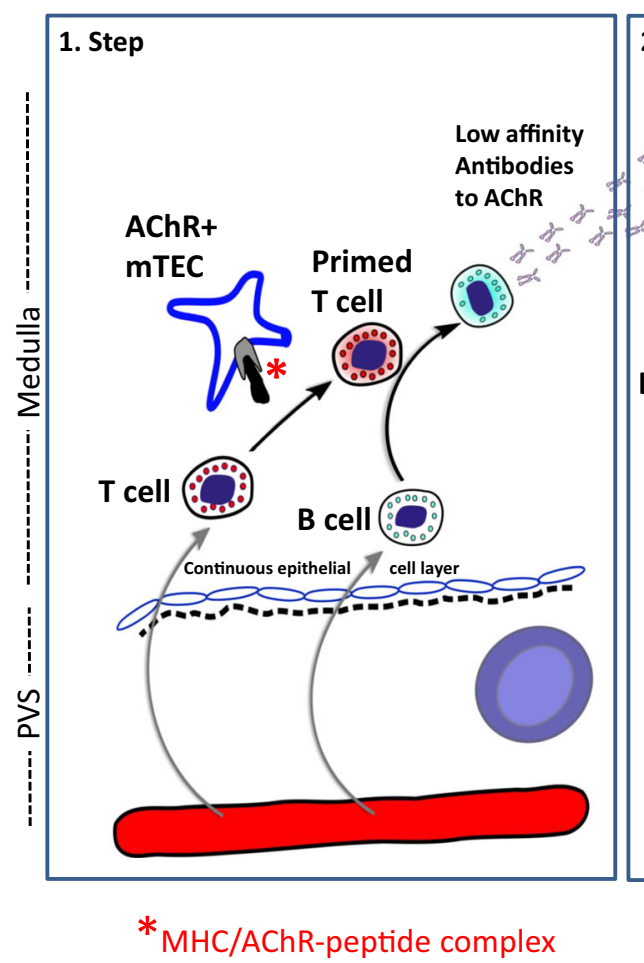

Fig. 3 Two-step intrathymic pathogenetic model of early-onset myasthenia gravis. Step 1: On re-entry of acetylcholine receptor (AChR)-reactive T-cells from the blood to the thymus, the T-cells (activated by unknown triggers) get 'primed' by medullary thymic epithelial cells (mTECs) expressing MHC/AChR-peptide complexes. The primed T-cells activate thymic B-cells to produce low-affinity antiAChR antibodies. Step 2: These autoantibodies bind to thymic myoid cells (TMCs) expressing native AChRs, activate complement and

the focal acquisition of a neoplastic AIRE-deficient clone of thymic epithelial cells in adult thymoma patients who already have an established normal peripheral immune repertoire. The clinical variability among thymoma patients has given clues to the pathogenesis of TAMG [18]:

1. Strong gender and genetic risk factors apparently contribute little to its development (Table 1), suggesting that the tumour is its main etiological factor.

2. Strongly thymopoietic thymomas confer greater TAMGsusceptibility than those with poor thymopoiesis; thymic carcinomas without thymopoiesis almost never develop MG [214].

3. Thymomas that generate naïve $\mathrm{CD} 4^{+} \mathrm{T}$-cells that then contribute to the peripheral TH-cell repertoire associate more strongly with TAMG than others that fail to 'export' single positive $\mathrm{CD}^{+}$progeny $[212,217]$. Also, TAMG(+) thymomas appear enriched for AChR-reactive thymocytes [218]. The reason for this dichotomy at the level of $\mathrm{CD} 4^{+} \mathrm{T}$-cells is only partly understood [219]. By contrast, export of $\mathrm{CD} 8^{+} \mathrm{T}$ cells from thymomas is maintained irrespective of MG status [217].

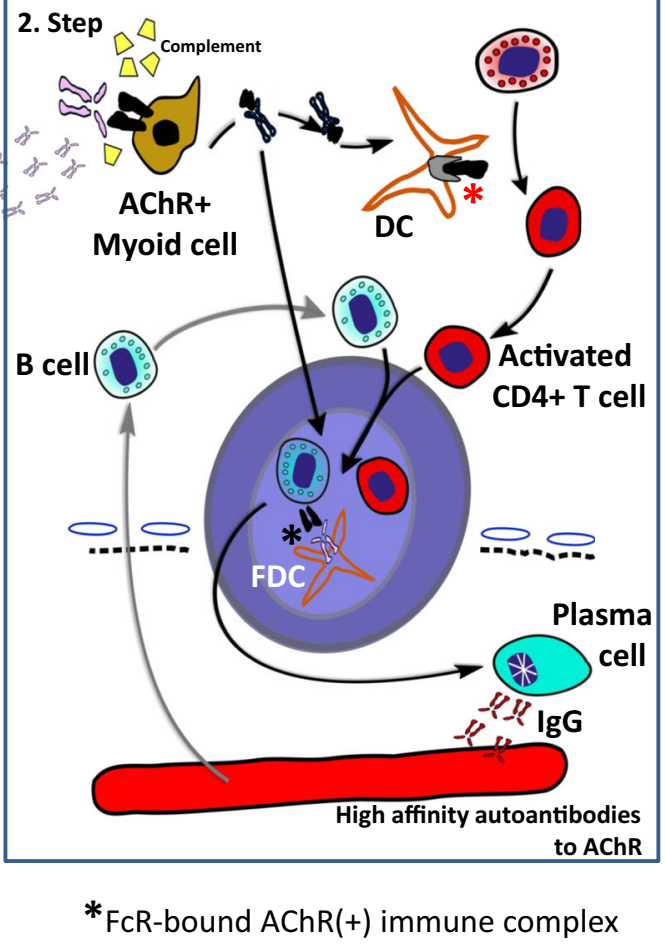

induce the release of $\mathrm{AChR} / \mathrm{antibody}$ complexes from TMC for processing by nearby dendritic cells (DCs) that bind to follicular dendritic cells (FDCs). The germinal centre (GC) reaction finally results in plasma cells producing high-affinity anti-AChR autoantibodies. It is unknown whether lymphoid follicles arise primarily in the PVS (as shown on the left and in Fig. 1d) or in the medulla, and why AChRreactive T-cells occur very commonly in the 'physiological' T-cell repertoire of healthy humans

4. In sharp contrast with the findings in EOMG thymi [191], conformation-specific autoantibodies to AChRs are not produced by cells from thymomas [100, 220, 221]. However, other autoantibodies against IFN- $\alpha$ S or IL-12 are produced by thymoma plasma cells; moreover, their titres usually rise sharply when thymomas recur, suggesting immunisation against linear epitopes within the tumours [221].

5. With rare exceptions [22, 222], levels of mRNA encoding the AChR $\alpha$-subunit are higher in TAMG(+) thymomas than in TAMG $(-)$ thymomas, hinting at immunisation there rather than tolerance induction $[22,100,214,221]$, unlike in the normal thymus [82]. Similarly, IFN- $\alpha$ s are present in thymomas [190], obviously AIRE-independent and clearly fail to tolerise there - again contravening standard dogma [14]. AIRE reportedly has additional tolerogenic actions [223]. If so, their loss may create aberrant thymic environments where it becomes 'dangerous' to express autoantigens. Wolff et al. [22] therefore proposed two parallel mechanisms in APECD thymi: in one, T-cells are actively auto-immunised, exported and go onto attack early, especially causing the unusual TH17 cell, parathyroid and adrenocortical failures, which mostly appear by ages $5-10$ (in $\sim 90$ to $\sim 70 \%$ of patients); in another scenario, T-cells 
simply fail to get tolerised, e.g. versus insulin, which happens randomly, much later and less frequently.

The following abnormalities in thymomas could, in theory, contribute to the development of TAMG, but surprisingly are also common in TAMG(-) thymomas [18, 210, 211, 215, 224-226]: the frequently reduced expression of MHCII antigens on TECs; the common MHC haploinsufficiency of TECs due to loss of $6 \mathrm{p} 21$; the reduced expression of proteases in cTECs (e.g. PRSS16); the reduced size of medullary compared with cortical areas; the lack of $\mathrm{AIRE}^{+}$mTECs and of Hassall corpuscles; the defective generation of FOXP ${ }^{+}$Tregs in thymomas; the paucity of B-cells and TMCs (Fig. 4).

Together, the findings have suggested a 4-step pathogenetic model for most thymomas that show thymopoiesis and express AChR/Titin epitopes:

1. Biased positive selection of developing specific TH-cells by neoplastic linear AChR/titin peptide-overexpressing TECs with cortical features expressing reduced levels of some HLA variants [211, 214, 224]

2 . These self-reactive TH-cells survive or are even preprimed in situ by their target autoantigens, partly because of the absence of AIRE $^{+}$mTECs and Tregs [190], also because of combined defects of medullary functions (including lack of myoid cell-derived AChRs and titin for tolerogenic cross-presentation by APCs)

3. Autoreactive mature TH-cells pass the bottleneck to terminal maturation [217], and escape apoptosis in thymomas [219], exit to the blood and 'infiltrate' the existing tolerant $\mathrm{T}$-cell repertoire with thymomaderived autoreactive T-cells [212, 218]

4. In the periphery [209], including the remnant thymus [221], these escaping autoreactive TH-cells stimulate Bcells to generate autoantibodies against native AChR after appropriate stimulation [217]. Once initiated, skeletal muscle-derived AChR/autoantibody complexes presented in regional lymph nodes perpetuate TAMG even after thymoma removal [227].

For the rare thymomas without thymopoiesis and $\mathrm{AChR} /$ Titin expression, alternative pathogenetic models may apply [18].

Finally, one should not forget that thymomas are malignant tumours that often require oncological interventions. Due to their propensity to 'poison' the immune system with potentially autoreactive $\mathrm{CD}^{+}$and $\mathrm{CD}^{+} \mathrm{T}$ cells [217], thymomas are exceptionally risky targets for immune checkpoint inhibitors, since they can unleash severe if not fatal autoreactivities particularly focused on skeletal and cardiac muscle [228].

\section{Conclusion}

Thymic tolerance-inducing mechanisms and their failure are extremely complex and have been difficult to study, particularly in humans, in whom autoimmune syndromes have
Fig. 4 Typical abnormalities of a thymoma with extensive thymopoiesis. a Conventional hematoxylin-eosin stain with predominant (dark) cortical areas and tiny (light staining) medullary regions. b TdT stain highlights extensive positively stained cortical areas (C) and small, unstained 'medullary island' (MI). c Absence of B-cells throughout the tumour (PAX5 stain). Note absence of Hassall corpuscles (due to absence of AIRE expression, not shown ). Immunoperoxidase
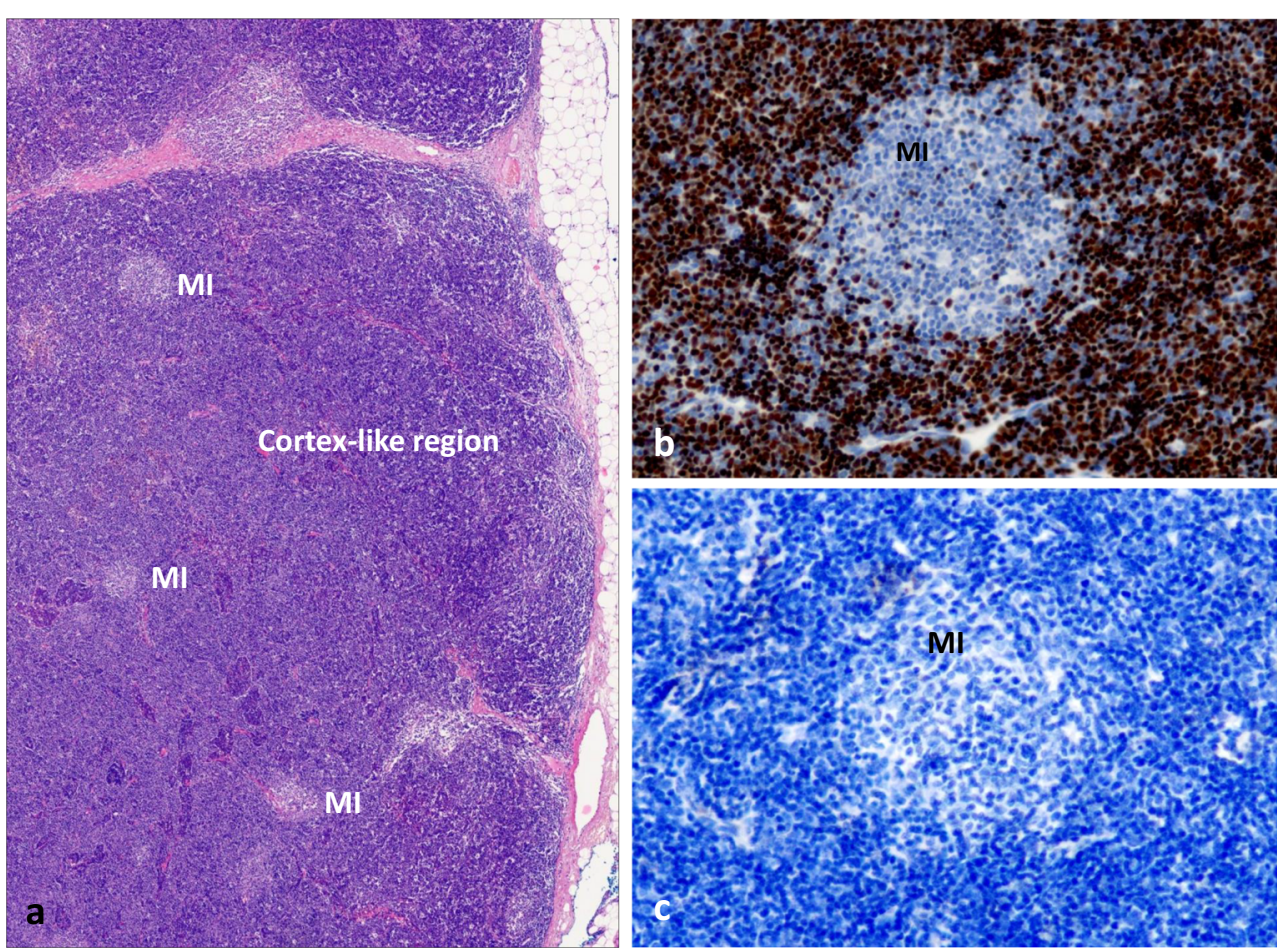
crucially spotlighted relevant genes and their actions. Novel single cell and spatial transcriptomic approaches, in conjunction with multiplex imaging techniques, have the potential to open new perspectives when applied to normal and diseased human thymus and appropriate mouse models.

\section{Compliance with ethical standards}

Conflict of interest The authors declare that they have no conflict of interest.

Open Access This article is licensed under a Creative Commons Attribution 4.0 International License, which permits use, sharing, adaptation, distribution and reproduction in any medium or format, as long as you give appropriate credit to the original author(s) and the source, provide a link to the Creative Commons licence, and indicate if changes were made. The images or other third party material in this article are included in the article's Creative Commons licence, unless indicated otherwise in a credit line to the material. If material is not included in the article's Creative Commons licence and your intended use is not permitted by statutory regulation or exceeds the permitted use, you will need to obtain permission directly from the copyright holder. To view a copy of this licence, visit http://creativecommons.org/licenses/by/4.0/.

\section{References}

1. Kappler JW, Roehm N, Marrack P (1987) T cell tolerance by clonal elimination in the thymus. Cell 49(2):273-280. https:// doi.org/10.1016/0092-8674(87)90568-x

2. Kisielow P, Teh HS, Blüthmann H, von Boehmer H (1988) Positive selection of antigen-specific T cells in thymus by restricting MHC molecules. Nature 335(6192):730-733. https:// doi.org/10.1038/335730a0

3. Brunkow ME, Jeffery EW, Hjerrild KA, Paeper B, Clark LB, Yasayko SA, Wilkinson JE, Galas D, Ziegler SF, Ramsdell F (2001) Disruption of a new forkhead/winged-helix protein, scurfin, results in the fatal lymphoproliferative disorder of the scurfy mouse. Nat Genet 27(1):68-73. https://doi.org/10.1038/ 83784

4. Hori S, Nomura T, Sakaguchi S (2003) Control of regulatory T cell development by the transcription factor Foxp3. Science (New York, NY) 299(5609):1057-1061. https://doi.org/10.1126/ science. 1079490

5. Fontenot JD, Gavin MA, Rudensky AY (2003) Foxp3 programs the development and function of CD4+CD25+ regulatory T cells. Nat Immunol 4(4):330-336. https://doi.org/10.1038/ni904

6. Sakaguchi S, Sakaguchi N, Asano M, Itoh M, Toda M (1995) Immunologic self-tolerance maintained by activated $\mathrm{T}$ cells expressing IL-2 receptor alpha-chains (CD25). Breakdown of a single mechanism of self-tolerance causes various autoimmune diseases. J Immunol (Baltimore, Md : 1950) 155(3):1151-1164

7. Cheng M, Anderson MS (2018) Thymic tolerance as a key brake on autoimmunity. Nat Immunol 19(7):659-664. https://doi.org/ 10.1038/s41590-018-0128-9

8. Gallegos AM, Bevan MJ (2004) Central tolerance to tissuespecific antigens mediated by direct and indirect antigen presentation. J Exp Med 200(8):1039-1049. https://doi.org/10.1084/ jem.20041457

9. APECED (1997) An autoimmune disease, APECED, caused by mutations in a novel gene featuring two PHD-type zinc-finger domains. Nat Genet 17(4):399-403. https://doi.org/10.1038/ ng1297-399

10. Nagamine K, Peterson P, Scott HS, Kudoh J, Minoshima S, Heino M, Krohn KJ, Lalioti MD, Mullis PE, Antonarakis SE, Kawasaki K, Asakawa S, Ito F, Shimizu N (1997) Positional cloning of the APECED gene. Nat Genet 17(4):393-398. https://doi.org/10. 1038/ng1297-393

11. Bennett CL, Christie J, Ramsdell F, Brunkow ME, Ferguson PJ, Whitesell L, Kelly TE, Saulsbury FT, Chance PF, Ochs HD (2001) The immune dysregulation, polyendocrinopathy, enteropathy, X-linked syndrome (IPEX) is caused by mutations of FOXP3. Nat Genet 27(1):20-21. https://doi.org/10.1038/83713

12. Cavadini P, Vermi W, Facchetti F, Fontana S, Nagafuchi S, Mazzolari E, Sediva A, Marrella V, Villa A, Fischer A, Notarangelo LD, Badolato R (2005) AIRE deficiency in thymus of 2 patients with Omenn syndrome. J Clin Invest 115(3):728 732. https://doi.org/10.1172/jci23087

13. Giardino G, Borzacchiello C, De Luca M, Romano R, Prencipe R, Cirillo E, Pignata C (2020) T-cell immunodeficiencies with congenital alterations of thymic development: genes implicated and differential immunological and clinical features. Front Immunol 11:1837. https://doi.org/10.3389/fimmu.2020.01837

14. Anderson MS, Venanzi ES, Klein L, Chen Z, Berzins SP, Turley SJ, von Boehmer H, Bronson R, Dierich A, Benoist C, Mathis D (2002) Projection of an immunological self shadow within the thymus by the AIRE protein. Science (New York, NY) 298(5597):1395-1401. https://doi.org/10.1126/science.1075958

15. Aschenbrenner K, D'Cruz LM, Vollmann EH, Hinterberger M, Emmerich J, Swee LK, Rolink A, Klein L (2007) Selection of Foxp3+ regulatory $\mathrm{T}$ cells specific for self antigen expressed and presented by AIRE+ medullary thymic epithelial cells. Nat Immunol 8(4):351-358. https://doi.org/10.1038/ni1444

16. Derbinski J, Schulte A, Kyewski B, Klein L (2001) Promiscuous gene expression in medullary thymic epithelial cells mirrors the peripheral self. Nat Immunol 2(11):1032-1039. https://doi.org/10. 1038/ni723

17. Sudres M, Verdier J, Truffault F, Le Panse R, Berrih-Aknin S (2018) Pathophysiological mechanisms of autoimmunity. Ann N Y Acad Sci 1413(1):59-68. https://doi.org/10.1111/nyas.13560

18. Marx A, Porubsky S, Belharazem D, Saruhan-Direskeneli G, Schalke B, Strobel P, Weis CA (2015) Thymoma related myasthenia gravis in humans and potential animal models. Exp Neurol 270:55-65. https://doi.org/10.1016/j.expneurol.2015.02.010

19. Laakso SM, Laurinolli T-T, Rossi LH, Lehtoviita A, Sairanen H, Perheentupa J, Kekäläinen E, Arstila TP (2010) Regulatory T cell defect in APECED patients is associated with loss of naive FOXP3(+) precursors and impaired activated population. J Autoimmun 35(4):351-357. https://doi.org/10.1016/j.jaut.2010. 07.008

20. Husebye ES, Perheentupa J, Rautemaa R, Kämpe O (2009) Clinical manifestations and management of patients with autoimmune polyendocrine syndrome type I. J Intern Med 265(5):514 529. https://doi.org/10.1111/j.1365-2796.2009.02090.x

21. Pöntynen N, Miettinen A, Arstila TP, Kämpe O, Alimohammadi M, Vaarala O, Peltonen L, Ulmanen I (2006) AIRE deficient mice do not develop the same profile of tissue-specific autoantibodies as APECED patients. J Autoimmun 27(2):96-104. https://doi.org/ 10.1016/j.jaut.2006.06.001

22. Wolff AS, Karner J, Owe JF, Oftedal BE, Gilhus NE, Erichsen MM, Kampe O, Meager A, Peterson P, Kisand K, Willcox N, Husebye ES (2014) Clinical and serologic parallels to APS-I in patients with thymomas and autoantigen transcripts in their tumors. J Immunol (Baltimore, Md : 1950) 193(8):3880-3890. https://doi.org/10.4049/jimmunol.1401068

23. Akiyama T, Shimo Y, Yanai H, Qin J, Ohshima D, Maruyama Y, Asaumi Y, Kitazawa J, Takayanagi H, Penninger JM, Matsumoto 
M, Nitta T, Takahama Y, Inoue J (2008) The tumor necrosis factor family receptors RANK and CD40 cooperatively establish the thymic medullary microenvironment and self-tolerance. Immunity 29(3):423-437. https://doi.org/10.1016/j.immuni. 2008.06.015

24. Hikosaka Y, Nitta T, Ohigashi I, Yano K, Ishimaru N, Hayashi Y, Matsumoto M, Matsuo K, Penninger JM, Takayanagi H, Yokota Y, Yamada H, Yoshikai Y, Inoue J, Akiyama T, Takahama Y (2008) The cytokine RANKL produced by positively selected thymocytes fosters medullary thymic epithelial cells that express autoimmune regulator. Immunity 29(3):438-450. https://doi.org/ 10.1016/j.immuni.2008.06.018

25. Rossi SW, Kim MY, Leibbrandt A, Parnell SM, Jenkinson WE, Glanville SH, McConnell FM, Scott HS, Penninger JM, Jenkinson EJ, Lane PJ, Anderson G (2007) RANK signals from CD4(+)3(-) inducer cells regulate development of AIRE-expressing epithelial cells in the thymic medulla. J Exp Med 204(6):1267-1272. https:// doi.org/10.1084/jem.20062497

26. Abramson J, Giraud M, Benoist C, Mathis D (2010) AIRE's partners in the molecular control of immunological tolerance. Cell 140(1):123-135. https://doi.org/10.1016/j.cell.2009.12.030

27. St-Pierre C, Trofimov A, Brochu S, Lemieux S, Perreault C (2015) Differential features of AIRE- induced and AIREindependent promiscuous gene expression in thymic epithelial cells. J Immunol (Baltimore, Md : 1950) 195(2):498-506. https://doi.org/10.4049/jimmunol.1500558

28. Murata S, Sasaki K, Kishimoto T, Niwa S, Hayashi H, Takahama Y, Tanaka K (2007) Regulation of CD8+ T cell development by thymus-specific proteasomes. Science (New York, NY) 316(5829):1349-1353. https://doi.org/10.1126/science.1141915

29. Malchow S, Leventhal DS, Lee V, Nishi S, Socci ND, Savage PA (2016) AIRE enforces immune tolerance by directing autoreactive $\mathrm{T}$ cells into the regulatory $\mathrm{T}$ cell lineagE. Immunity 44(5):11021113. https://doi.org/10.1016/j.immuni.2016.02.009

30. Nedjic J, Aichinger M, Emmerich J, Mizushima N, Klein L (2008) Autophagy in thymic epithelium shapes the T-cell repertoire and is essential for tolerance. Nature 455(7211):396-400. https://doi.org/ 10.1038/nature 07208

31. Aichinger M, Wu C, Nedjic J, Klein L (2013) Macroautophagy substrates are loaded onto MHC class II of medullary thymic epithelial cells for central tolerance. J Exp Med 210(2):287-300. https://doi.org/10.1084/jem.20122149

32. Peterson P, Org T, Rebane A (2008) Transcriptional regulation by AIRE: molecular mechanisms of central tolerance. Nat Rev Immunol 8(12):948-957. https://doi.org/10.1038/nri2450

33. Danan-Gotthold M, Guyon C, Giraud M, Levanon EY, Abramson J (2016) Extensive RNA editing and splicing increase immune self-representation diversity in medullary thymic epithelial cells. Genome Biol 17(1):219. https://doi.org/10.1186/s13059-0161079-9

34. Kadouri N, Nevo S, Goldfarb Y, Abramson J (2020) Thymic epithelial cell heterogeneity: TEC by TEC. Nat Rev Immunol 20(4):239-253. https://doi.org/10.1038/s41577-019-0238-0

35. Giraud M, Yoshida H, Abramson J, Rahl PB, Young RA, Mathis D, Benoist C (2012) AIRE unleashes stalled RNA polymerase to induce ectopic gene expression in thymic epithelial cells. Proc Natl Acad Sci U S A 109(2):535-540. https://doi.org/10.1073/ pnas.1119351109

36. Bansal K, Yoshida H, Benoist C, Mathis D (2017) The transcriptional regulator AIRE binds to and activates super-enhancers. Nat Immunol 18(3):263-273. https://doi.org/10.1038/ni.3675

37. Pinto S, Michel C, Schmidt-Glenewinkel H, Harder N, Rohr K, Wild S, Brors B, Kyewski B (2013) Overlapping gene coexpression patterns in human medullary thymic epithelial cells generate self-antigen diversity. Proc Natl Acad Sci U S A 110(37): E3497-E3505. https://doi.org/10.1073/pnas. 1308311110
38. Guyon C, Jmari N, Padonou F, Li YC, Ucar O, Fujikado N, Coulpier F, Blanchet C, Root DE, Giraud M (2020) AIREdependent genes undergo Clp1-mediated 3'UTR shortening associated with higher transcript stability in the thymus. eLife 9: e52985. https://doi.org/10.7554/eLife.52985

39. Tomofuji Y, Takaba H, Suzuki HI, Benlaribi R, Martinez CDP, Abe Y, Morishita Y, Okamura T, Taguchi A, Kodama T, Takayanagi H (2020) Chd4 choreographs self-antigen expression for central immune tolerance. Nat Immunol 21(8):892-901. https://doi.org/10.1038/s41590-020-0717-2

40. Berrih-Aknin S, Panse RL, Dragin N (2018) AIRE: a missing link to explain female susceptibility to autoimmune diseases. Ann N Y Acad Sci 1412(1):21-32. https://doi.org/10.1111/nyas.13529

41. Cloosen S, Arnold J, Thio M, Bos GM, Kyewski B, Germeraad WT (2007) Expression of tumor-associated differentiation antigens, MUC1 glycoforms and CEA, in human thymic epithelial cells: implications for self-tolerance and tumor therapy. Cancer Res 67(8):3919-3926. https://doi.org/10.1158/0008-5472.can06-2112

42. Derbinski J, Pinto S, Rösch S, Hexel K, Kyewski B (2008) Promiscuous gene expression patterns in single medullary thymic epithelial cells argue for a stochastic mechanism. Proc Natl Acad Sci U S A 105(2):657-662. https://doi.org/10.1073/pnas. 0707486105

43. Lee BJ, Mace EM (2020) From stem cell to immune effector: how adhesion, migration, and polarity shape T-cell and natural killer cell lymphocyte development in vitro and in vivo. Mol Biol Cell 31(10):981-991. https://doi.org/10.1091/mbc.E19-08-0424

44. Duke-Cohan JS, Ishikawa Y, Yoshizawa A, Choi YI, Lee CN, Acuto O, Kissler S, Reinherz EL (2018) Regulation of thymocyte trafficking by Tagap, a GAP domain protein linked to human autoimmunity. Sci Signal 11(534):eaan8799. https://doi.org/10. 1126/scisignal.aan8799

45. Koble C, Kyewski B (2009) The thymic medulla: a unique microenvironment for intercellular self-antigen transfer. J Exp Med 206(7):1505-1513. https://doi.org/10.1084/jem.20082449

46. Hubert FX, Kinkel SA, Davey GM, Phipson B, Mueller SN, Liston A, Proietto AI, Cannon PZ, Forehan S, Smyth GK, Wu L, Goodnow CC, Carbone FR, Scott HS, Heath WR (2011) AIRE regulates the transfer of antigen from mTECs to dendritic cells for induction of thymic tolerance. Blood 118(9):2462-2472. https:// doi.org/10.1182/blood-2010-06-286393

47. Perry JSA, Russler-Germain EV, Zhou YW, Purtha W, Cooper ML, Choi J, Schroeder MA, Salazar V, Egawa T, Lee BC, Abumrad NA, Kim BS, Anderson MS, DiPersio JF, Hsieh CS (2018) Transfer of cell-surface antigens by scavenger receptor CD36 promotes thymic regulatory $\mathrm{T}$ cell receptor repertoire development and allo-tolerance. Immunity 48(6):1271. https://doi. org/10.1016/j.immuni.2018.05.011

48. Michel C, Miller CN, Küchler R, Brors B, Anderson MS, Kyewski B, Pinto S (2017) Revisiting the road map of medullary thymic epithelial cell differentiation. J Immunol (Baltimore, Md : 1950) 199(10):3488-3503. https://doi.org/10.4049/jimmunol. 1700203

49. Cepeda S, Cantu C, Orozco S, Xiao Y, Brown Z, Semwal MK, Venables T, Anderson MS, Griffith AV (2018) Age-associated decline in thymic B Cell Expression of AIRE and AIREdependent self-antigens. Cell Rep 22(5):1276-1287. https://doi. org/10.1016/j.celrep.2018.01.015

50. Gabrielsen ISM, Helgeland H, Akselsen H, Aass HCD, AYM S, Snowhite IV, Pugliese A, Flåm ST, Lie BA (2019) Transcriptomes of antigen presenting cells in human thymus. PLoS One 14(7):e0218858. https://doi.org/10.1371/journal.pone. 0218858

51. Perera J, Meng L, Meng F, Huang H (2013) Autoreactive thymic $\mathrm{B}$ cells are efficient antigen-presenting cells of cognate self- 
antigens for T cell negative selection. Proc Natl Acad Sci U S A 110(42):17011-17016. https://doi.org/10.1073/pnas.1313001110

52. Yamano T, Nedjic J, Hinterberger M, Steinert M, Koser S, Pinto S, Gerdes N, Lutgens E, Ishimaru N, Busslinger M, Brors B, Kyewski B, Klein L (2015) Thymic B cells are licensed to present self antigens for central $\mathrm{T}$ cell tolerance induction. Immunity 42(6):1048-1061. https://doi.org/10.1016/j.immuni.2015.05.013

53. Fergusson JR, Morgan MD, Bruchard M, Huitema L, Heesters BA, van Unen V, van Hamburg JP, van der Wel NN, Picavet D, Koning F, Tas SW, Anderson MS, Marioni JC, Hollander GA, Spits H (2018) Maturing human CD127+ CCR7+ PDL1+ dendritic cells express AIRE in the absence of tissue restricted antigens. Front Immunol 9:2902. https://doi.org/10.3389/fimmu.2018. 02902

54. Park JE, Botting RA, Domínguez Conde C, Popescu DM, Lavaert M, Kunz DJ, Goh I, Stephenson E, Ragazzini R, Tuck E, WilbreyClark A, Roberts K, Kedlian VR, Ferdinand JR, He X, Webb S, Maunder D, Vandamme N, Mahbubani KT, Polanski K, Mamanova L, Bolt L, Crossland D, de Rita F, Fuller A, Filby A, Reynolds G, Dixon D, Saeb-Parsy K, Lisgo S, Henderson D, Vento-Tormo R, Bayraktar OA, Barker RA, Meyer KB, Saeys Y, Bonfanti P, Behjati S, Clatworthy MR, Taghon T, Haniffa M, Teichmann SA (2020) A cell atlas of human thymic development defines $\mathrm{T}$ cell repertoire formation. Science (New York, NY) 367(6480):eaay3224. https://doi.org/10.1126/science.aay3224

55. Gardner JM, Metzger TC, McMahon EJ, Au-Yeung BB, Krawisz AK, Lu W, Price JD, Johannes KP, Satpathy AT, Murphy KM, Tarbell KV, Weiss A, Anderson MS (2013) Extrathymic AIREexpressing cells are a distinct bone marrow-derived population that induce functional inactivation of $\mathrm{CD}^{+} \mathrm{T}$ cells. Immunity 39(3):560-572. https://doi.org/10.1016/j.immuni.2013.08.005

56. Perry JSA, Lio CJ, Kau AL, Nutsch K, Yang Z, Gordon JI, Murphy KM, Hsieh CS (2014) Distinct contributions of AIRE and antigen-presenting-cell subsets to the generation of selftolerance in the thymus. Immunity 41(3):414-426. https://doi. org/10.1016/j.immuni.2014.08.007

57. Leonard JD, Gilmore DC, Dileepan T, Nawrocka WI, Chao JL, Schoenbach MH, Jenkins MK, Adams EJ, Savage PA (2017) Identification of natural regulatory $\mathrm{T}$ cell epitopes reveals convergence on a dominant autoantigen. Immunity 47(1):107-117.e108. https://doi.org/10.1016/j.immuni.2017.06.015

58. Taniguchi RT, DeVoss JJ, Moon JJ, Sidney J, Sette A, Jenkins MK, Anderson MS (2012) Detection of an autoreactive T-cell population within the polyclonal repertoire that undergoes distinct autoimmune regulator (AIRE)-mediated selection. Proc Natl Acad Sci U S A 109(20):7847-7852. https://doi.org/10.1073/pnas. 1120607109

59. Meager A, Visvalingam K, Peterson P, Möll K, Murumägi A, Krohn K, Eskelin P, Perheentupa J, Husebye E, Kadota Y, Willcox N (2006) Anti-interferon autoantibodies in autoimmune polyendocrinopathy syndrome type 1 . PLoS Med 3(7):e289e289. https://doi.org/10.1371/journal.pmed.0030289

60. Meloni A, Willcox N, Meager A, Atzeni M, Wolff ASB, Husebye ES, Furcas M, Rosatelli MC, Cao A, Congia M (2012) Autoimmune polyendocrine syndrome type 1: an extensive longitudinal study in Sardinian patients. J Clin Endocrinol Metab 97(4): 1114-1124. https://doi.org/10.1210/jc.2011-2461

61. Wolff AS, Sarkadi AK, Maródi L, Kärner J, Orlova E, Oftedal BE, Kisand K, Oláh E, Meloni A, Myhre AG, Husebye ES, Motaghedi R, Perheentupa J, Peterson P, Willcox N, Meager A (2013) Anticytokine autoantibodies preceding onset of autoimmune polyendocrine syndrome type I features in early childhood. J Clin Immunol 33(8):1341-1348. https://doi.org/10.1007/s10875013-9938-6

62. Kisand K, Bøe Wolff AS, Podkrajsek KT, Tserel L, Link M, Kisand KV, Ersvaer E, Perheentupa J, Erichsen MM, Bratanic
N, Meloni A, Cetani F, Perniola R, Ergun-Longmire B, Maclaren N, Krohn KJ, Pura M, Schalke B, Ströbel P, Leite MI, Battelino T, Husebye ES, Peterson P, Willcox N, Meager A (2010) Chronic mucocutaneous candidiasis in APECED or thymoma patients correlates with autoimmunity to Th17associated cytokines. J Exp Med 207(2):299-308. https://doi. org/10.1084/jem.20091669

63. Puel A, Döffinger R, Natividad A, Chrabieh M, Barcenas-Morales G, Picard C, Cobat A, Ouachée-Chardin M, Toulon A, Bustamante J, Al-Muhsen S, Al-Owain M, Arkwright PD, Costigan C, McConnell V, Cant AJ, Abinun M, Polak M, Bougnères PF, Kumararatne D, Marodi L, Nahum A, Roifman C, Blanche S, Fischer A, Bodemer C, Abel L, Lilic D, Casanova JL (2010) Autoantibodies against IL-17A, IL-17F, and IL-22 in patients with chronic mucocutaneous candidiasis and autoimmune polyendocrine syndrome type I. J Exp Med 207(2):291-297. https://doi.org/10.1084/jem.20091983

64. Meyer S, Woodward M, Hertel C, Vlaicu P, Haque Y, Kärner J, Macagno A, Onuoha SC, Fishman D, Peterson H, Metsküla K, Uibo R, Jäntti K, Hokynar K, Wolff ASB, collaborative Ap, Krohn K, Ranki A, Peterson P, Kisand K, Hayday A (2016) AIRE-deficient patients harbor unique high-affinity disease-ameliorating autoantibodies. Cell 166(3):582-595. https://doi.org/10. 1016/j.cell.2016.06.024

65. Fishman D, Kisand K, Hertel C, Rothe M, Remm A, Pihlap M, Adler P, Vilo J, Peet A, Meloni A, Podkrajsek KT, Battelino T, Bruserud Ø, Wolff ASB, Husebye ES, Kluger N, Krohn K, Ranki A, Peterson H, Hayday A, Peterson P (2017) Autoantibody repertoire in APECED patients targets two distinct subgroups of proteins. Front Immunol 8:976. https://doi.org/10.3389/fimmu.2017. 00976

66. Khan IS, Mouchess ML, Zhu ML, Conley B, Fasano KJ, Hou Y, Fong L, Su MA, Anderson MS (2014) Enhancement of an antitumor immune response by transient blockade of central $\mathrm{T}$ cell tolerance. J Exp Med 211(5):761-768. https://doi.org/10.1084/ jem.20131889

67. Su MA, Anderson MS (2019) Pulling RANK on cancer: blocking AIRE-mediated central tolerance to enhance immunotherapY. Cancer Immunol Res 7(6):854-859. https://doi.org/10.1158/ 2326-6066.cir-18-0912

68. Tazi-Ahnini R, McDonagh AJ, Wengraf DA, Lovewell TR, Vasilopoulos Y, Messenger AG, Cork MJ, Gawkrodger DJ (2008) The autoimmune regulator gene (AIRE) is strongly associated with vitiligo. Br J Dermatol 159(3):591-596. https://doi. org/10.1111/j.1365-2133.2008.08718.x

69. Bérczi B, Gerencsér G, Farkas N, Hegyi P, Veres G, Bajor J, Czopf L, Alizadeh H, Rakonczay Z, Vigh É, Eröss B, Szemes K, Gyöngyi Z (2017) Association between AIRE gene polymorphism and rheumatoid arthritis: a systematic review and metaanalysis of case-control studies. Sci Rep 7(1):14096. https://doi. org/10.1038/s41598-017-14375-Z

70. Turunen JA, Wessman M, Forsblom C, Kilpikari R, Parkkonen M, Pöntynen N, Ilmarinen T, Ulmanen I, Peltonen L, Groop PH (2006) Association analysis of the AIRE and insulin genes in Finnish type 1 diabetic patients. Immunogenetics 58(5-6):331338. https://doi.org/10.1007/s00251-006-0088-3

71. Mathieu AL, Verronese E, Rice GI, Fouyssac F, Bertrand Y, Picard C, Chansel M, Walter JE, Notarangelo LD, Butte MJ, Nadeau KC, Csomos K, Chen DJ, Chen K, Delgado A, Rigal C, Bardin C, Schuetz C, Moshous D, Reumaux H, Plenat F, Phan A, Zabot MT, Balme B, Viel S, Bienvenu J, Cochat P, van der Burg M, Caux C, Kemp EH, Rouvet I, Malcus C, Méritet JF, Lim A, Crow YJ, Fabien N, Ménétrier-Caux C, De Villartay JP, Walzer T, Belot A (2015) PRKDC mutations associated with immunodeficiency, granuloma, and autoimmune regulator-dependent 
autoimmunity. J Allergy Clin Immunol 135(6):1578-1588.e1575. https://doi.org/10.1016/j.jaci.2015.01.040

72. Takaba H, Morishita Y, Tomofuji Y, Danks L, Nitta T, Komatsu N, Kodama T, Takayanagi H (2015) Fezf2 Orchestrates a thymic program of self-antigen expression for immune tolerance. Cell 163(4):975-987. https://doi.org/10.1016/j.cell.2015.10.013

73. Guo C, Eckler MJ, McKenna WL, McKinsey GL, Rubenstein JL, Chen B (2013) Fezf2 expression identifies a multipotent progenitor for neocortical projection neurons, astrocytes, and oligodendrocytes. Neuron 80(5):1167-1174. https://doi.org/10.1016/j. neuron.2013.09.037

74. Hirata T, Suda Y, Nakao K, Narimatsu M, Hirano T, Hibi M (2004) Zinc finger gene fez-like functions in the formation of subplate neurons and thalamocortical axons. Dev Dyn : an official publication of the American Association of Anatomists 230(3): 546-556. https://doi.org/10.1002/dvdy.20068

75. Tzartos JS, Stergiou C, Daoussis D, Zisimopoulou P, Andonopoulos AP, Zolota V, Tzartos SJ (2017) Antibodies to aquaporins are frequent in patients with primary Sjögren's syndrome. Rheumatology (Oxford) 56(12):2114-2122. https://doi. org/10.1093/rheumatology/kex328

76. Clement CC, Moncrieffe H, Lele A, Janow G, Becerra A, Bauli F, Saad FA, Perino G, Montagna C, Cobelli N, Hardin J, Stern LJ, Ilowite N, Porcelli SA, Santambrogio L (2016) Autoimmune response to transthyretin in juvenile idiopathic arthritis. JCI Insight 1(2):e85633. https://doi.org/10.1172/jci.insight.85633

77. Marín-Sánchez A, Álvarez-Sierra D, González O, Lucas-Martin A, Sellés-Sánchez A, Rudilla F, Enrich E, Colobran R, PujolBorrell R (2019) Regulation of TSHR expression in the thyroid and thymus may contribute to TSHR tolerance failure in Graves' disease patients via two distinct mechanisms. Front Immunol 10: 1695. https://doi.org/10.3389/fimmu.2019.01695

78. McLachlan SM, Aliesky HA, Banuelos B, Lesage S, Collin R, Rapoport B (2017) High-level intrathymic thyrotrophin receptor expression in thyroiditis-prone mice protects against the spontaneous generation of pathogenic thyrotrophin receptor autoantibodies. Clin Exp Immunol 188(2):243-253. https://doi.org/10. 1111/cei.12928

79. Pugliese A, Zeller M, Fernandez A Jr, Zalcberg LJ, Bartlett RJ, Ricordi C, Pietropaolo M, Eisenbarth GS, Bennett ST, Patel DD (1997) The insulin gene is transcribed in the human thymus and transcription levels correlated with allelic variation at the INS VNTR-IDDM2 susceptibility locus for type 1 diabetes. Nat Genet 15(3):293-297. https://doi.org/10.1038/ng0397-293

80. Vafiadis P, Bennett ST, Todd JA, Nadeau J, Grabs R, Goodyer CG, Wickramasinghe S, Colle E, Polychronakos C (1997) Insulin expression in human thymus is modulated by INS VNTR alleles at the IDDM2 locus. Nat Genet 15(3):289-292. https://doi.org/10. 1038/ng0397-289

81. Paquette J, Varin DS, Hamelin CE, Hallgren A, Kämpe O, Carel JC, Perheentupa J, Deal CL (2010) Risk of autoimmune diabetes in APECED: association with short alleles of the 5'insulin VNTR. Genes Immun 11(7):590-597. https://doi.org/10.1038/gene.2010. 33

82. Giraud M, Taubert R, Vandiedonck C, Ke X, Levi-Strauss M, Pagani F, Baralle FE, Eymard B, Tranchant C, Gajdos P, Vincent A, Willcox N, Beeson D, Kyewski B, Garchon HJ (2007) An IRF8-binding promoter variant and AIRE control CHRNA1 promiscuous expression in thymus. Nature 448(7156):934-937. https://doi.org/10.1038/nature06066

83. Lv H, Havari E, Pinto S, Gottumukkala RV, Cornivelli L, Raddassi K, Matsui T, Rosenzweig A, Bronson RT, Smith R, Fletcher AL, Turley SJ, Wucherpfennig K, Kyewski B, Lipes MA (2011) Impaired thymic tolerance to $\alpha$-myosin directs autoimmunity to the heart in mice and humans. J Clin Invest 121(4): 1561-1573. https://doi.org/10.1172/jci44583
84. Odaka C, Hauri-Hohl M, Takizawa K, Nishikawa Y, Yano M, Matsumoto M, Boyd R, Hollander GA (2013) TGF-beta type II receptor expression in thymic epithelial cells inhibits the development of Hassall's corpuscles in mice. Int Immunol 25(11):633642. https://doi.org/10.1093/intimm/dxt026

85. Bornstein C, Nevo S, Giladi A, Kadouri N, Pouzolles M, Gerbe F, David E, Machado A, Chuprin A, Toth B, Goldberg O, Itzkovitz S, Taylor N, Jay P, Zimmermann VS, Abramson J, Amit I (2018) Single-cell mapping of the thymic stroma identifies IL-25producing tuft epithelial cells. Nature 559(7715):622-626. https://doi.org/10.1038/s41586-018-0346-1

86. Miller CN, Proekt I, von Moltke J, Wells KL, Rajpurkar AR, Wang H, Rattay K, Khan IS, Metzger TC, Pollack JL, Fries AC, Lwin WW, Wigton EJ, Parent AV, Kyewski B, Erle DJ, Hogquist KA, Steinmetz LM, Locksley RM, Anderson MS (2018) Thymic tuft cells promote an IL-4-enriched medulla and shape thymocyte development. Nature 559(7715):627-631. https://doi.org/10. 1038/s41586-018-0345-2

87. White AJ, Nakamura K, Jenkinson WE, Saini M, Sinclair C, Seddon B, Narendran P, Pfeffer K, Nitta T, Takahama Y, Caamano JH, Lane PJ, Jenkinson EJ, Anderson G (2010) Lymphotoxin signals from positively selected thymocytes regulate the terminal differentiation of medullary thymic epithelial cells. J Immunol (Baltimore, Md : 1950) 185(8):4769-4776. https://doi.org/10.4049/jimmunol.1002151

88. Van de Velde RL, Friedman NB (1970) Thymic myoid cells and myasthenia gravis. Am J Pathol 59(2):347-368

89. Hanabuchi S, Ito T, Park WR, Watanabe N, Shaw JL, Roman E, Arima K, Wang YH, Voo KS, Cao W, Liu YJ (2010) Thymic stromal lymphopoietin-activated plasmacytoid dendritic cells induce the generation of FOXP3+ regulatory T cells in human thymus. J Immunol (Baltimore, Md : 1950) 184(6):2999-3007. https://doi.org/10.4049/jimmunol.0804106

90. Watanabe N, Wang YH, Lee HK, Ito T, Wang YH, Cao W, Liu YJ (2005) Hassall's corpuscles instruct dendritic cells to induce $\mathrm{CD} 4+\mathrm{CD} 25+$ regulatory $\mathrm{T}$ cells in human thymus. Nature 436(7054):1181-1185. https://doi.org/10.1038/nature03886

91. van Ewijk W (1988) Cell surface topography of thymic microenvironments. Lab Invest; a Journal of technical methods and pathology 59(5):579-590

92. Banerjee A, McKinley ET, von Moltke J, Coffey RJ, Lau KS (2018) Interpreting heterogeneity in intestinal tuft cell structure and function. J Clin Invest 128(5):1711-1719. https://doi.org/10. $1172 /$ jci 120330

93. Gerbe F, Legraverend C, Jay P (2012) The intestinal epithelium tuft cells: specification and function. Cell Mol Life Sci : CMLS 69(17):2907-2917. https://doi.org/10.1007/s00018-012-0984-7

94. Nevo S, Kadouri N, Abramson J (2019) Tuft cells: from the mucosa to the thymus. Immunol Lett 210:1-9. https://doi.org/10. 1016/j.imlet.2019.02.003

95. McGinty JW, Ting HA, Billipp TE, Nadjsombati MS, Khan DM, Barrett NA, Liang HE, Matsumoto I, von Moltke J (2020) Tuftcell-derived leukotrienes drive rapid anti-helminth immunity in the small intestine but are dispensable for anti-protist immunity. Immunity 52(3):528-541.e527. https://doi.org/10.1016/j.immuni. 2020.02.005

96. Hu B, Simon-Keller K, Kuffer S, Strobel P, Braun T, Marx A, Porubsky S (2016) Myf5 and myogenin in the development of thymic myoid cells - implications for a murine in vivo model of myasthenia gravis. Exp Neurol 277:76-85. https://doi.org/10. 1016/j.expneurol.2015.12.010

97. Wekerle TH, Paterson B, Ketelsen U, Feldman M (1975) Striated muscle fibres differentiate in monolayer cultures of adult thymus reticulum. Nature 256(5517):493-494. https://doi.org/10.1038/ $256493 \mathrm{a} 0$ 
98. Schluep M, Willcox N, Vincent A, Dhoot GK, Newsom-Davis J (1987) Acetylcholine receptors in human thymic myoid cells in situ: an immunohistological study. Ann Neurol 22(2):212-222. https://doi.org/10.1002/ana.410220205

99. Marx A, Osborn M, Tzartos S, Geuder KI, Schalke B, Nix W, Kirchner T, Muller-Hermelink HK (1992) A striational muscle antigen and myasthenia gravis-associated thymomas share an acetylcholine-receptor epitope. Dev Immunol 2(2):77-84

100. Romi F, Bø L, Skeie GO, Myking A, Aarli JA, Gilhus NE (2002) Titin and ryanodine receptor epitopes are expressed in cortical thymoma along with costimulatory molecules. J Neuroimmunol 128(1-2):82-89. https://doi.org/10.1016/s0165-5728(02)00145-5

101. Wakkach A, Guyon T, Bruand C, Tzartos S, Cohen-Kaminsky S, Berrih-Aknin S (1996) Expression of acetylcholine receptor genes in human thymic epithelial cells: implications for myasthenia gravis. J Immunol (Baltimore, Md : 1950) 157(8):3752-3760

102. Giménez-Barcons $\mathrm{M}$, Casteràs $\mathrm{A}$, Armengol Mdel $\mathrm{P}$, Porta $\mathrm{E}$, Correa PA, Marín A, Pujol-Borrell R, Colobran R (2014) Autoimmune predisposition in Down syndrome may result from a partial central tolerance failure due to insufficient intrathymic expression of AIRE and peripheral antigens. J Immunol (Baltimore, Md : 1950) 193(8):3872-3879. https://doi.org/10. 4049/jimmunol.1400223

103. Mortimer GL, Gillespie KM (2020) Early onset of autoimmune diabetes in children with Down syndrome-two separate aetiologies or an immune system pre-programmed for autoimmunity? Curr Diab Rep 20(9):47. https://doi.org/10.1007/s11892-020-01318-8

104. Skogberg G, Lundberg V, Lindgren S, Gudmundsdottir J, Sandström K, Kämpe O, Annerén G, Gustafsson J, Sunnegårdh J, van der Post S, Telemo E, Berglund M, Ekwall O (2014) Altered expression of autoimmune regulator in infant down syndrome thymus, a possible contributor to an autoimmune phenotype. J Immunol (Baltimore, Md : 1950) 193(5):2187-2195. https://doi.org/10.4049/jimmunol.1400742

105. Steinmann GG, Klaus B, Muller-Hermelink HK (1985) The involution of the ageing human thymic epithelium is independent of puberty. A morphometric study. Scand J Immunol 22(5):563-575

106. Thomas R, Wang W, Su DM (2020) Contributions of age-related thymic involution to immunosenescence and inflammaging. Immun Ageing : I \& A 17:2. https://doi.org/10.1186/s12979020-0173-8

107. Cooper GS, Stroehla BC (2003) The epidemiology of autoimmune diseases. Autoimmun Rev 2(3):119-125. https://doi.org/ 10.1016/s1568-9972(03)00006-5

108. Vobořil M, Brabec T, Dobeš J, Šplíchalová I, Březina J, Čepková A, Dobešová M, Aidarova A, Kubovčiak J, Tsyklauri O, Štěpánek O, Beneš V, Sedláček R, Klein L, Kolář M, Filipp D (2020) Tolllike receptor signaling in thymic epithelium controls monocytederived dendritic cell recruitment and Treg generation. Nat Commun 11(1):2361. https://doi.org/10.1038/s41467-02016081-3

109. Gurka S, Dirks S, Photiadis J, Kroczek RA (2015) Expression analysis of surface molecules on human thymic dendritic cells with the 10th HLDA Workshop antibody panel. Clin Transl Immunol 4(10):e47. https://doi.org/10.1038/cti.2015.21

110. Wu L, Shortman K (2005) Heterogeneity of thymic dendritic cells. Semin Immunol 17(4):304-312. https://doi.org/10.1016/j.smim. 2005.05.001

111. Cosway EJ, Ohigashi I, Schauble K, Parnell SM, Jenkinson WE, Luther S, Takahama Y, Anderson G (2018) Formation of the intrathymic dendritic cell pool requires CCL21-mediated recruitment of CCR7(+) progenitors to the thymus. J Immunol (Baltimore, Md : 1950) 201(2):516-523. https://doi.org/10.4049/ jimmunol.1800348

112. Bonasio R, Scimone ML, Schaerli P, Grabie N, Lichtman AH, von Andrian UH (2006) Clonal deletion of thymocytes by circulating dendritic cells homing to the thymus. Nat Immunol 7(10):10921100. https://doi.org/10.1038/ni1385

113. Hadeiba H, Lahl K, Edalati A, Oderup C, Habtezion A, Pachynski R, Nguyen L, Ghodsi A, Adler S, Butcher EC (2012) Plasmacytoid dendritic cells transport peripheral antigens to the thymus to promote central tolerance. Immunity 36(3):438-450. https://doi.org/10.1016/j.immuni.2012.01.017

114. Lei Y, Ripen AM, Ishimaru N, Ohigashi I, Nagasawa T, Jeker LT, Bösl MR, Holländer GA, Hayashi Y, Malefyt Rde W, Nitta T, Takahama Y (2011) AIRE-dependent production of XCL1 mediates medullary accumulation of thymic dendritic cells and contributes to regulatory T cell development. J Exp Med 208(2):383394. https://doi.org/10.1084/jem.20102327

115. Lancaster JN, Thyagarajan HM, Srinivasan J, Li Y, Hu Z, Ehrlich LIR (2019) Live-cell imaging reveals the relative contributions of antigen-presenting cell subsets to thymic central tolerance. Nat Commun 10(1):2220. https://doi.org/10.1038/s41467-01909727-4

116. Hu Z, Li Y, Van Nieuwenhuijze A, Selden HJ, Jarrett AM, Sorace AG, Yankeelov TE, Liston A, Ehrlich LIR (2017) CCR7 Modulates the generation of thymic regulatory $\mathrm{T}$ cells by altering the composition of the thymic dendritic cell compartment. Cell Rep 21(1):168-180. https://doi.org/10.1016/j.celrep.2017.09.016

117. Isaacson PG, Norton AJ, Addis BJ (1987) The human thymus contains a novel population of B lymphocytes. Lancet (London, England) 2(8574):1488-1491

118. Perera J, Zheng Z, Li S, Gudjonson H, Kalinina O, Benichou JIC, Block KE, Louzoun Y, Y in D, Chong AS, Dinner AR, Weigert M, Huang H (2016) Self-antigen-driven thymic B cell class switching promotes T cell central tolerance. Cell Rep 17(2):387-398. https:// doi.org/10.1016/j.celrep.2016.09.011

119. Gies V, Guffroy A, Danion F, Billaud P, Keime C, Fauny JD, Susini S, Soley A, Martin T, Pasquali JL, Gros F, AndreSchmutz I, Soulas-Sprauel P, Korganow AS (2017) B cells differentiate in human thymus and express AIRE. J Allergy Clin Immunol 139(3):1049-1052.e1012. https://doi.org/10.1016/j. jaci.2016.09.044

120. Lu FT, Yang W, Wang YH, Ma HD, Tang W, Yang JB, Li L, Ansari AA, Lian ZX (2015) Thymic B cells promote thymusderived regulatory $\mathrm{T}$ cell development and proliferation. $\mathrm{J}$ Autoimmun 61:62-72. https://doi.org/10.1016/j.jaut.2015.05.008

121. Walters SN, Webster KE, Daley S, Grey ST (2014) A role for intrathymic $\mathrm{B}$ cells in the generation of natural regulatory $\mathrm{T}$ cells. J Immunol (Baltimore, Md : 1950) 193(1):170-176. https://doi. org/10.4049/jimmunol.1302519

122. Xing C, Ma N, Xiao H, Wang X, Zheng M, Han G, Chen G, Hou C, Shen B, Li Y, Wang R (2015) Critical role for thymic CD19+ CD5+CD1 dhilL-10+ regulatory B cells in immune homeostasis. J Leukoc Biol 97(3):547-556. https://doi.org/10.1189/jlb.3A0414$213 R R$

123. Ono M (2020) Control of regulatory T-cell differentiation and function by T-cell receptor signalling and Foxp3 transcription factor complexes. Immunology 160(1):24-37. https://doi.org/10. 1111/imm.13178

124. Hsieh CS, Zheng Y, Liang Y, Fontenot JD, Rudensky AY (2006) An intersection between the self-reactive regulatory and nonregulatory $\mathrm{T}$ cell receptor repertoires. Nat Immunol 7(4): 401-410. https://doi.org/10.1038/ni1318

125. Shevach EM, Thornton AM (2014) tTregs, pTregs, and iTregs: similarities and differences. Immunol Rev 259(1):88-102. https:// doi.org/10.1111/imr.12160

126. Kitagawa Y, Ohkura N, Kidani Y, Vandenbon A, Hirota K, Kawakami R, Yasuda K, Motooka D, Nakamura S, Kondo M, Taniuchi I, Kohwi-Shigematsu T, Sakaguchi S (2017) Guidance of regulatory $\mathrm{T}$ cell development by Satb1-dependent super- 
enhancer establishment. Nat Immunol 18(2):173-183. https://doi. org/10.1038/ni.3646

127. Polansky JK, Kretschmer K, Freyer J, Floess S, Garbe A, Baron U, Olek S, Hamann A, von Boehmer H, Huehn J (2008) DNA methylation controls Foxp3 gene expression. Eur J Immunol 38(6): 1654-1663. https://doi.org/10.1002/eji.200838105

128. Ohkura N, Sakaguchi S (2020) Transcriptional and epigenetic basis of Treg cell development and function: its genetic anomalies or variations in autoimmune diseases. Cell Res 30(6):465-474. https://doi.org/10.1038/s41422-020-0324-7

129. Owen DL, Mahmud SA, Sjaastad LE, Williams JB, Spanier JA, Simeonov DR, Ruscher R, Huang W, Proekt I, Miller CN, Hekim C, Jeschke JC, Aggarwal P, Broeckel U, LaRue RS, Henzler CM, Alegre ML, Anderson MS, August A, Marson A, Zheng Y, Williams CB, Farrar MA (2019) Thymic regulatory T cells arise via two distinct developmental programs. Nat Immunol 20(2): 195-205. https://doi.org/10.1038/s41590-018-0289-6

130. Varas A, Sacedón R, Hernandez-López C, Jiménez E, GarcíaCeca J, Arias-Díaz J, Zapata AG, Vicente A (2003) Agedependent changes in thymic macrophages and dendritic cells. Microsc Res Tech 62(6):501-507. https://doi.org/10.1002/jemt. 10411

131. Ki S, Park D, Selden HJ, Seita J, Chung H, Kim J, Iyer VR, Ehrlich LIR (2014) Global transcriptional profiling reveals distinct functions of thymic stromal subsets and age-related changes during thymic involution. Cell Rep 9(1):402-415. https://doi.org/10. 1016/j.celrep.2014.08.070

132. Sempowski GD, Hale LP, Sundy JS, Massey JM, Koup RA, Douek DC, Patel DD, Haynes BF (2000) Leukemia inhibitory factor, oncostatin M, IL-6, and stem cell factor mRNA expression in human thymus increases with age and is associated with thymic atrophy. J Immunol (Baltimore, Md : 1950) 164(4):2180-2187. https://doi.org/10.4049/jimmunol.164.4.2180

133. Chatila TA, Blaeser F, Ho N, Lederman HM, Voulgaropoulos C, Helms C, Bowcock AM (2000) JM2, encoding a fork head-related protein, is mutated in $\mathrm{X}$-linked autoimmunity-allergic disregulation syndrome. J Clin Invest 106(12):R75-R81. https:// doi.org/10.1172/jci11679

134. Barzaghi F, Amaya Hernandez LC, Neven B, Ricci S, Kucuk ZY, Bleesing JJ, Nademi Z, Slatter MA, Ulloa ER, Shcherbina A, Roppelt A, Worth A, Silva J, Aiuti A, Murguia-Favela L, Speckmann C, Carneiro-Sampaio M, Fernandes JF, Baris S, Ozen A, Karakoc-Aydiner E, Kiykim A, Schulz A, Steinmann S, Notarangelo LD, Gambineri E, Lionetti P, Shearer WT, Forbes LR, Martinez C, Moshous D, Blanche S, Fisher A, Ruemmele FM, Tissandier C, Ouachee-Chardin M, RieuxLaucat F, Cavazzana M, Qasim W, Lucarelli B, Albert MH, Kobayashi I, Alonso L, Diaz De Heredia C, Kanegane H, Lawitschka A, Seo JJ, Gonzalez-Vicent M, Diaz MA, Goyal RK, Sauer MG, Yesilipek A, Kim M, Yilmaz-Demirdag Y, Bhatia M, Khlevner J, Richmond Padilla EJ, Martino S, Montin D, Neth O, Molinos-Quintana A, Valverde-Fernandez J, Broides A, Pinsk V, Ballauf A, Haerynck F, Bordon V, Dhooge C, GarciaLloret ML, Bredius RG, Kałwak K, Haddad E, Seidel MG, Duckers G, Pai S-Y, Dvorak CC, Ehl S, Locatelli F, Goldman F, Gennery AR, Cowan MJ, Roncarolo M-G, Bacchetta R, Primary Immune Deficiency Treatment $\mathrm{C}$, the Inborn Errors Working Party of the European Society for B, Marrow T (2018) Longterm follow-up of IPEX syndrome patients after different therapeutic strategies: an international multicenter retrospective study. $\mathrm{J}$ Allergy Clin Immunol 141(3):1036-1049.e1035. https://oi.org/ 10.1016/j.jaci.2017.10.041

135. Cepika AM, Sato Y, Liu JM, Uyeda MJ, Bacchetta R, Roncarolo MG (2018) Tregopathies: monogenic diseases resulting in regulatory T-cell deficiency. J Allergy Clin Immunol 142(6):16791695. https://doi.org/10.1016/j.jaci.2018.10.026
136. Ohkura N, Yasumizu Y, Kitagawa Y, Tanaka A, Nakamura Y, Motooka D, Nakamura S, Okada Y, Sakaguchi S (2020) Regulatory $\mathrm{T}$ cell-specific epigenomic region variants are a key determinant of susceptibility to common autoimmune diseases. Immunity 52(6):1119-1132.e1114. https://doi.org/10.1016/j. immuni.2020.04.006

137. Costa-Carvalho BT, de Moraes-Pinto MI, de Almeida LC, de Seixas Alves MT, Maia RP, de Souza RL, Barreto M, Lourenço L, Vicente AM, Coutinho A, Carneiro-Sampaio M (2008) A remarkable depletion of both naïve CD4+ and CD8+ with high proportion of memory $\mathrm{T}$ cells in an IPEX infant with a FOXP3 mutation in the forkhead domain. Scand J Immunol 68(1):85-91. https://doi.org/10.1111/j.1365-3083.2008.02055.x

138. Liston A, Gray DHD, Lesage S, Fletcher AL, Wilson J, Webster KE, Scott HS, Boyd RL, Peltonen L, Goodnow CC (2004) Gene dosage-limiting role of AIRE in thymic expression, clonal deletion, and organ-specific autoimmunity. J Exp Med 200(8):10151026. https://doi.org/10.1084/jem.20040581

139. Guerder S, Hassel C, Carrier A (2019) Thymus-specific serine protease, a protease that shapes the CD4 $\mathrm{T}$ cell repertoire. Immuno Gen 71(3):223-232. https://doi.org/10.1007/s00251018-1078-y

140. Liu H, Jain R, Guan J, Vuong V, Ishido S, La Gruta NL, Gray DH, Villadangos JA, Mintern JD (2016) Ubiquitin ligase MARCH 8 cooperates with CD83 to control surface MHC II expression in thymic epithelium and CD4 T cell selection. J Exp Med 213(9): 1695-1703. https://doi.org/10.1084/jem.20160312

141. von Rohrscheidt J, Petrozziello E, Nedjic J, Federle C, Krzyzak L, Ploegh HL, Ishido S, Steinkasserer A, Klein L (2016) Thymic CD4 $\mathrm{T}$ cell selection requires attenuation of March8-mediated MHCII turnover in cortical epithelial cells through CD83. J Exp Med 213(9):1685-1694. https://doi.org/10.1084/jem.20160316

142. Sakaguchi N, Takahashi T, Hata H, Nomura T, Tagami T, Yamazaki S, Sakihama T, Matsutani T, Negishi I, Nakatsuru S, Sakaguchi S (2003) Altered thymic T-cell selection due to a mutation of the ZAP-70 gene causes autoimmune arthritis in mice. Nature 426(6965):454 460. https://doi.org/10.1038/nature02119

143. Verhagen J, Genolet R, Britton GJ, Stevenson BJ, Sabatos-Peyton CA, Dyson J, Luescher IF, Wraith DC (2013) CTLA-4 controls the thymic development of both conventional and regulatory $\mathrm{T}$ cells through modulation of the TCR repertoire. Proc Natl Acad Sci U S A 110(3):E221-E230. https://doi.org/10.1073/pnas. 1208573110

144. Yamaguchi T, Kishi A, Osaki M, Morikawa H, Prieto-Martin P, Wing K, Saito T, Sakaguchi S (2013) Construction of selfrecognizing regulatory $\mathrm{T}$ cells from conventional $\mathrm{T}$ cells by controlling CTLA-4 and IL-2 expression. Proc Natl Acad Sci U S A 110(23):E2116-E2125. https://doi.org/10.1073/pnas.1307185110

145. Misslitz A, Pabst O, Hintzen G, Ohl L, Kremmer E, Petrie HT, Förster R (2004) Thymic T cell development and progenitor localization depend on CCR7. J Exp Med 200(4):481-491. https:// doi.org/10.1084/jem.20040383

146. Ueno T, Hara K, Willis MS, Malin MA, Hopken UE, Gray DH, Matsushima K, Lipp M, Springer TA, Boyd RL, Yoshie O, Takahama Y (2002) Role for CCR7 ligands in the emigration of newly generated $\mathrm{T}$ lymphocytes from the neonatal thymus. Immunity 16(2):205-218

147. Kurobe H, Liu C, Ueno T, Saito F, Ohigashi I, Seach N, Arakaki R, Hayashi Y, Kitagawa T, Lipp M, Boyd RL, Takahama Y (2006) CCR7-dependent cortex-to-medulla migration of positively selected thymocytes is essential for establishing central tolerance. Immunity 24(2):165-177. https://doi.org/10.1016/j.immuni. 2005.12.011

148. Nitta T, Kochi Y, Muro R, Tomofuji Y, Okamura T, Murata S, Suzuki H, Sumida T, Yamamoto K, Takayanagi H (2017) Human thymoproteasome variations influence CD8 T cell selection. Sci 
Immunol 2(12):eaan5165. https://doi.org/10.1126/sciimmunol. aan5165

149. Viret C, Leung-Theung-Long S, Serre L, Lamare C, Vignali DA, Malissen B, Carrier A, Guerder S (2011) Thymus-specific serine protease controls autoreactive CD4 T cell development and autoimmune diabetes in mice. J Clin Invest 121(5):1810-1821. https:// doi.org/10.1172/jci43314

150. Schuster C, Gerold KD, Schober K, Probst L, Boerner K, Kim MJ, Ruckdeschel A, Serwold T, Kissler S (2015) The autoimmunityassociated gene CLEC16A modulates thymic epithelial cell autophagy and alters $\mathrm{T}$ cell selection. Immunity 42(5):942-952. https://doi.org/10.1016/j.immuni.2015.04.011

151. Hsu LY, Tan YX, Xiao Z, Malissen M, Weiss A (2009) A hypomorphic allele of ZAP-70 reveals a distinct thymic threshold for autoimmune disease versus autoimmune reactivity. J Exp Med 206(11):2527-2541. https://doi.org/10.1084/jem.20082902

152. Chan AY, Punwani D, Kadlecek TA, Cowan MJ, Olson JL, Mathes EF, Sunderam U, Fu SM, Srinivasan R, Kuriyan J, Brenner SE, Weiss A, Puck JM (2016) A novel human autoimmune syndrome caused by combined hypomorphic and activating mutations in ZAP-70. J Exp Med 213(2):155-165. https://doi.org/ 10.1084/jem.20150888

153. Yin C, Pei XY, Shen H, Gao YN, Sun XY, Wang W, Ge Q, Zhang $\mathrm{Y}(2017)$ Thymic homing of activated CD4(+) T cells induces degeneration of the thymic epithelium through excessive RANK signaling. Sci Rep 7(1):2421. https://doi.org/10.1038/s41598017-02653-9

154. Zhang J, Wang Y, Aili A, Sun X, Pang X, Ge Q, Zhang Y, Jin R (2019) Th1 biased progressive autoimmunity in aged AIREdeficient mice accelerated thymic epithelial cell senescence. Aging Dis 10(3):497-509. https://doi.org/10.14336/ad.2018.0608

155. Flores KG, Li J, Hale LP (2001) B cells in epithelial and perivascular compartments of human adult thymus. Hum Pathol 32(9):926-934. https://doi.org/10.1053/hupa.2001.27106

156. Flores KG, Li J, Sempowski GD, Haynes BF, Hale LP (1999) Analysis of the human thymic perivascular space during aging. J Clin Invest 104(8):1031-1039. https://doi.org/10.1172/jci7558

157. James KD, Jenkinson WE, Anderson G (2018) T-cell egress from the thymus: should I stay or should I go? J Leukoc Biol 104(2): 275-284. https://doi.org/10.1002/jlb.1mr1217-496r

158. Lancaster JN, Li Y, Ehrlich LIR (2018) Chemokine-mediated choreography of thymocyte development and selection. Trends Immunol 39(2):86-98. https://doi.org/10.1016/j.it.2017.10.007

159. Nunez S, Moore C, Gao B, Rogers K, Hidalgo Y, Del Nido PJ, Restaino S, Naka Y, Bhagat G, Madsen JC, Bono MR, Zorn E (2016) The human thymus perivascular space is a functional niche for viral-specific plasma cells. Sci Immunol 1(6):eaah4447. https://doi.org/10.1126/sciimmunol.aah4447

160. Korostoff JM, Nakada MT, Faas SJ, Blank KJ, Gaulton GN (1990) Neonatal exposure to thymotropic gross murine leukemia virus induces virus-specific immunologic nonresponsiveness. J Exp Med 172(6):1765-1775. https://doi.org/10.1084/jem.172.6. 1765

161. Du X, Zeng H, Liu S, Guy C, Dhungana Y, Neale G, Bergo MO, Chi H (2020) Mevalonate metabolism-dependent protein geranylgeranylation regulates thymocyte egress. J Exp Med 217(2):e20190969. https://doi.org/10.1084/jem.20190969

162. Saba JD (2017) The low down on sphingosine-1-phosphate lyase as a regulator of thymic egress. J Immunol Sci 1(1):1-8. https:// doi.org/10.29245/2578-3009/2018/1.1103

163. Shiow LR, Roadcap DW, Paris K, Watson SR, Grigorova IL, Lebet T, An J, Xu Y, Jenne CN, Föger N, Sorensen RU, Goodnow CC, Bear JE, Puck JM, Cyster JG (2008) The actin regulator coronin $1 \mathrm{~A}$ is mutant in a thymic egress-deficient mouse strain and in a patient with severe combined immunodeficiency. Nat Immunol 9(11):1307-1315. https://doi.org/10.1038/ni.1662
164. Zachariah MA, Cyster JG (2010) Neural crest-derived pericytes promote egress of mature thymocytes at the corticomedullary junction. Science (New York, NY) 328(5982):1129-1135. https://doi.org/10.1126/science.1188222

165. Resop RS, Douaisi M, Craft J, Jachimowski LC, Blom B, Uittenbogaart CH (2016) Sphingosine-1-phosphate/sphingosine1-phosphate receptor 1 signaling is required for migration of naive human $\mathrm{T}$ cells from the thymus to the periphery. $\mathrm{J}$ Allergy Clin Immunol 138(2):551-557.e558. https://doi.org/10.1016/j.jaci. 2015.12.1339

166. James KD, Cosway EJ, Lucas B, White AJ, Parnell SM, CarvalhoGaspar M, Tumanov AV, Anderson G, Jenkinson WE (2018) Endothelial cells act as gatekeepers for LTbetaR-dependent thymocyte emigration. J Exp Med 215(12):2984-2993. https://doi. org/10.1084/jem.20181345

167. Dang TS, Willet JD, Griffin HR, Morgan NV, O'Boyle G, Arkwright PD, Hughes SM, Abinun M, Tee LJ, Barge D, Engelhardt KR, Jackson M, Cant AJ, Maher ER, Koref MS, Reynard LN, Ali S, Hambleton S (2016) Defective leukocyte adhesion and chemotaxis contributes to combined immunodeficiency in humans with autosomal recessive MST1 Deficiency. J Clin Immunol 36(2):117-122. https://doi.org/10.1007/s10875016-0232-2

168. Halacli SO, Ayvaz DC, Sun-Tan C, Erman B, Uz E, Yilmaz DY, Ozgul K, Tezcan İ, Sanal O (2015) STK4 (MST1) deficiency in two siblings with autoimmune cytopenias: a novel mutation. Clin Immunol (Orlando, Fla) 161(2):316-323. https://doi.org/10.1016/ j.clim.2015.06.010

169. Shi H, Liu C, Tan H, Li Y, Nguyen TM, Dhungana Y, Guy C, Vogel P, Neale G, Rankin S, Feng Y, Peng J, Tao W, Chi H (2018) Hippo kinases Mst1 and Mst2 sense and amplify IL-2RSTAT5 signaling in regulatory T cells to establish stable regulatory activity. Immunity 49(5):899-914.e896. https://doi.org/10. 1016/j.immuni.2018.10.010

170. Nehme NT, Schmid JP, Debeurme F, André-Schmutz I, Lim A, Nitschke P, Rieux-Laucat F, Lutz P, Picard C, Mahlaoui N, Fischer A, de Saint Basile G (2012) MST1 mutations in autosomal recessive primary immunodeficiency characterized by defective naive T-cell survival. Blood 119(15):3458-3468. https://doi.org/ 10.1182/blood-2011-09-378364

171. Schipp C, Schlütermann D, Hönscheid A, Nabhani S, Höll J, Oommen PT, Ginzel S, Fleckenstein B, Stork B, Borkhardt A, Stepensky P, Fischer U (2018) EBV negative lymphoma and autoimmune lymphoproliferative syndrome like phenotype extend the clinical spectrum of primary immunodeficiency caused by STK4 deficiency. Front Immunol 9:2400. https://doi.org/10. 3389/fimmu.2018.02400

172. Yagi H, Matsumoto M, Nakamura M, Makino S, Suzuki R, Harada M, Itoh T (1996) Defect of thymocyte emigration in a T cell deficiency strain (CTS) of the mouse. J Immunol (Baltimore, Md : 1950) 157(8):3412-3419

173. Gilhus NE, Verschuuren JJ (2016) Myasthenia gravis: subgroup classifications - authors' reply. Lancet Neurol 15(4):357-358. https://doi.org/10.1016/s1474-4422(16)00035-1

174. Chuang WY, Ströbel P, Belharazem D, Rieckmann P, Toyka KV, Nix W, Schalke B, Gold R, Kiefer R, Klinker E, Opitz A, Inoue M, Kuo TT, Müller-Hermelink HK, Marx A (2009) The PTPN22gain-of-function+1858T(+) genotypes correlate with low IL-2 expression in thymomas and predispose to myasthenia gravis. Genes Immun 10(8):667-672. https://doi.org/10.1038/ gene.2009.64

175. Chuang WY, Strobel P, Bohlender-Willke AL, Rieckmann P, Nix W, Schalke B, Gold R, Opitz A, Klinker E, Inoue M, MullerHermelink HK, Saruhan-Direskeneli G, Bugert P, Willcox N, Marx A (2014) Late-onset myasthenia gravis - CTLA4(low) genotype association and low-for-age thymic output of naive $\mathrm{T}$ cells. 
J Autoimmun 52:122-129. https://doi.org/10.1016/j.jaut.2013.12. 006

176. Chuang WY, Ströbel P, Gold R, Nix W, Schalke B, Kiefer R, Opitz A, Klinker E, Müller-Hermelink HK, Marx A (2005) A CTLA4high genotype is associated with myasthenia gravis in thymoma patients. Ann Neurol 58(4):644-648. https://doi.org/ 10.1002/ana.20577

177. Gregersen PK, Kosoy R, Lee AT, Lamb J, Sussman J, McKee D, Simpfendorfer KR, Pirskanen-Matell R, Piehl F, PanHammarstrom Q, Verschuuren JJ, Titulaer MJ, Niks EH, Marx A, Strobel P, Tackenberg B, Putz M, Maniaol A, Elsais A, Tallaksen C, Harbo HF, Lie BA, Raychaudhuri S, de Bakker PI, Melms A, Garchon HJ, Willcox N, Hammarstrom L, Seldin MF (2012) Risk for myasthenia gravis maps to a (151) Pro->Ala change in TNIP1 and to human leukocyte antigen-B*08. Ann Neurol 72(6):927-935. https://doi.org/10.1002/ana.23691

178. Maniaol AH, Elsais A, Lorentzen AR, Owe JF, Viken MK, Saether H, Flam ST, Brathen G, Kampman MT, Midgard R, Christensen M, Rognerud A, Kerty E, Gilhus NE, Tallaksen CM, Lie BA, Harbo HF (2012) Late onset myasthenia gravis is associated with HLA DRB1*15:01 in the Norwegian population. PLoS One 7(5):e36603. https://doi.org/10.1371/journal.pone. 0036603

179. Renton AE, Pliner HA, Provenzano C, Evoli A, Ricciardi R, Nalls MA, Marangi G, Abramzon Y, Arepalli S, Chong S, Hernandez DG, Johnson JO, Bartoccioni E, Scuderi F, Maestri M, Gibbs JR, Errichiello E, Chio A, Restagno G, Sabatelli M, Macek M, Scholz SW, Corse A, Chaudhry V, Benatar M, Barohn RJ, McVey A, Pasnoor M, Dimachkie MM, Rowin J, Kissel J, Freimer M, Kaminski HJ, Sanders DB, Lipscomb B, Massey JM, Chopra M, Howard JF Jr, Koopman WJ, Nicolle MW, Pascuzzi RM, Pestronk A, Wulf C, Florence J, Blackmore D, Soloway A, Siddiqi Z, Muppidi S, Wolfe G, Richman D, Mezei MM, Jiwa T, Oger J, Drachman DB, Traynor BJ (2015) A genome-wide association study of myasthenia gravis. JAMA Neurol 72(4): 396-404. https://doi.org/10.1001/jamaneurol.2014.4103

180. Seldin MF, Alkhairy OK, Lee AT, Lamb JA, Sussman J, Pirskanen-Matell R, Piehl F, Verschuuren J, Kostera-Pruszczyk A, Szczudlik P, McKee D, Maniaol AH, Harbo HF, Lie BA, Melms A, Garchon HJ, Willcox N, Gregersen PK, Hammarstrom L (2016) Genome-wide association study of lateonset myasthenia gravis: confirmation of TNFRSF11A and identification of ZBTB10 and three distinct HLA associations. Mol Med (Cambridge, Mass) 21(1):769-781. https://doi.org/10.2119/ molmed.2015.00232

181. Tackenberg B, Schlegel K, Happel M, Eienbröker C, Gellert K, Oertel WH, Meager A, Willcox N, Sommer N (2009) Expanded TCR Vbeta subsets of CD8(+) T-cells in late-onset myasthenia gravis: novel parallels with thymoma patients. J Neuroimmunol 216(1-2):85-91. https://doi.org/10.1016/j.jneuroim.2009.08.018

182. Leite MI, Strobel P, Jones M, Micklem K, Moritz R, Gold R, Niks EH, Berrih-Aknin S, Scaravilli F, Canelhas A, Marx A, NewsomDavis J, Willcox N, Vincent A (2005) Fewer thymic changes in MuSK antibody-positive than in MuSK antibody-negative MG. Ann Neurol 57(3):444-448. https://doi.org/10.1002/ana.20386

183. Romi F, Hong Y, Gilhus NE (2017) Pathophysiology and immunological profile of myasthenia gravis and its subgroups. Curr Opin Immunol 49:9-13. https://doi.org/10.1016/j.coi.2017.07. 006

184. Marx A, Pfister F, Schalke B, Saruhan-Direskeneli G, Melms A, Strobel P (2013) The different roles of the thymus in the pathogenesis of the various myasthenia gravis subtypes. Autoimmun Rev 12(9):875-884. https://doi.org/10.1016/j.autrev.2013.03.007

185. Weis CA, Schalke B, Strobel P, Marx A (2018) Challenging the current model of early-onset myasthenia gravis pathogenesis in the light of the MGTX trial and histological heterogeneity of thymectomy specimens. Ann N Y Acad Sci 1413(1):82-91. https://doi.org/10.1111/nyas.13563

186. Gilhus NE, Verschuuren JJ (2015) Myasthenia gravis: subgroup classification and therapeutic strategies. Lancet Neurol 14(10): 1023-1036. https://doi.org/10.1016/s1474-4422(15)00145-3

187. Gilhus NE, Romi F, Hong Y, Skeie GO (2018) Myasthenia gravis and infectious disease. J Neurol 265(6):1251-1258. https://doi. org/10.1007/s00415-018-8751-9

188. Cron MA, Maillard S, Villegas J, Truffault F, Sudres M, Dragin N, Berrih-Aknin S, Le Panse R (2018) Thymus involvement in earlyonset myasthenia gravis. Ann N Y Acad Sci 1412(1):137-145. https://doi.org/10.1111/nyas.13519

189. Wekerle H, Ketelsen UP (1977) Intrathymic pathogenesis and dual genetic control of myasthenia gravis. Lancet (London, England) 1(8013):678-680. https://doi.org/10.1016/s01406736(77)92118-3

190. Willcox N, Leite MI, Kadota Y, Jones M, Meager A, Subrahmanyam P, Dasgupta B, Morgan BP, Vincent A (2008) Autoimmunizing mechanisms in thymoma and thymus. Ann N Y Acad Sci 1132:163-173. https://doi.org/10.1196/annals.1405. 021

191. Vincent A, Scadding GK, Thomas HC, Newsom-Davis J (1978) In-vitro synthesis of anti-acetylcholine-receptor antibody by thymic lymphocytes in myasthenia gravis. Lancet (London, England) 1(8059):305-307

192. Sims GP, Shiono H, Willcox N, Stott DI (2001) Somatic hypermutation and selection of B cells in thymic germinal centers responding to acetylcholine receptor in myasthenia gravis. J Immunol (Baltimore, Md : 1950) 167(4):1935-1944. https://doi. org/10.4049/jimmunol.167.4.1935

193. Weinberg CB, Hall ZW (1979) Antibodies from patients with myasthenia gravis recognize determinants unique to extrajunctional acetylcholine receptors. Proc Natl Acad Sci U S A 76(1):504-508. https://doi.org/10.1073/pnas.76.1.504

194. Kirchner T, Schalke B, Melms A, von Kugelgen T, MullerHermelink HK (1986) Immunohistological patterns of nonneoplastic changes in the thymus in myasthenia gravis. Virchows Archiv B: Cell Pathology including Molecular Pathology 52(3):237-257

195. Roxanis I, Micklem K, McConville J, Newsom-Davis J, Willcox $\mathrm{N}$ (2002) Thymic myoid cells and germinal center formation in myasthenia gravis; possible roles in pathogenesis. J Neuroimmunol 125(1-2):185-197

196. Leite MI, Jones M, Strobel P, Marx A, Gold R, Niks E, Verschuuren JJ, Berrih-Aknin S, Scaravilli F, Canelhas A, Morgan BP, Vincent A, Willcox N (2007) Myasthenia gravis thymus: complement vulnerability of epithelial and myoid cells, complement attack on them, and correlations with autoantibody status. Am J Pathol 171(3):893-905. https://doi.org/10.2353/ ajpath.2007.070240

197. Safar D, Aimé C, Cohen-Kaminsky S, Berrih-Aknin S (1991) Antibodies to thymic epithelial cells in myasthenia gravis. $\mathrm{J}$ Neuroimmunol 35(1-3):101-110. https://doi.org/10.1016/01655728(91)90165-4

198. Meraouna A, Cizeron-Clairac G, Panse RL, Bismuth J, Truffault F, Tallaksen C, Berrih-Aknin S (2006) The chemokine CXCL13 is a key molecule in autoimmune myasthenia gravis. Blood 108(2):432-440. https://doi.org/10.1182/blood-2005-06-2383

199. Wolfe GI, Kaminski HJ, Aban IB, Minisman G, Kuo HC, Marx A, Strobel P, Mazia C, Oger J, Cea JG, Heckmann JM, Evoli A, Nix W, Ciafaloni E, Antonini G, Witoonpanich R, King JO, Beydoun SR, Chalk CH, Barboi AC, Amato AA, Shaibani AI, Katirji B, Lecky BRF, Buckley C, Vincent A, Dias-Tosta E, Yoshikawa H, Waddington-Cruz M, Pulley MT, Rivner MH, Kostera-Pruszczyk A, Pascuzzi RM, Jackson CE, Verschuuren J, Massey JM, Kissel JT, Werneck LC, Benatar M, Barohn RJ, Tandan R, Mozaffar T, 
Silvestri NJ, Conwit R, Sonett JR, Jaretzki A 3rd, Newsom-Davis J, Cutter GR (2019) Long-term effect of thymectomy plus prednisone versus prednisone alone in patients with non-thymomatous myasthenia gravis: 2-year extension of the MGTX randomised trial. Lancet Neurol. https://doi.org/10.1016/s1474-4422(18) 30392-2

200. Hohlfeld R, Wekerle H (2008) Reflections on the "intrathymic pathogenesis" of myasthenia gravis. J Neuroimmunol 201-202: 21-27. https://doi.org/10.1016/j.jneuroim.2008.05.020

201. Melms A, Malcherek G, Gern U, Wiethölter H, Müller CA, Schoepfer R, Lindstrom J (1992) T cells from normal and myasthenic individuals recognize the human acetylcholine receptor: heterogeneity of antigenic sites on the alpha-subunit. Ann Neurol 31(3):311-318. https://doi.org/10.1002/ana.410310314

202. Sommer N, Harcourt GC, Willcox N, Beeson D, Newsom-Davis J (1991) Acetylcholine receptor-reactive T lymphocytes from healthy subjects and myasthenia gravis patients. Neurology 41(8):1270-1276. https://doi.org/10.1212/wnl.41.8.1270

203. Thiault N, Darrigues J, Adoue V, Gros M, Binet B, Perals C, Leobon B, Fazilleau N, Joffre OP, Robey EA, van Meerwijk JP, Romagnoli P (2015) Peripheral regulatory T lymphocytes recirculating to the thymus suppress the development of their precursors. Nat Immunol 16(6):628-634. https://doi.org/10.1038/ni. 3150

204. Pinto AI, Smith J, Kissack MR, Hogg KG, Green EA (2018) Thymic B cell-mediated attack of thymic stroma precedes type 1 diabetes development. Front Immunol 9:1281. https://doi.org/10. 3389/fimmu.2018.01281

205. Bornemann A, Kirchner T (1998) Thymic myoid cell turnover in myasthenia gravis patients and in normal controls. Virchows Archiv : an international journal of pathology 432(4):357-361. https://doi.org/10.1007/s004280050178

206. Balandina A, Lécart S, Dartevelle P, Saoudi A, Berrih-Aknin S (2005) Functional defect of regulatory CD4(+)CD25+ T cells in the thymus of patients with autoimmune myasthenia gravis. Blood 105(2):735-741. https://doi.org/10.1182/blood-2003-11-3900

207. Truffault F, Nazzal D, Verdier J, Gradolatto A, Fadel E, Roussin R, Eymard B, Le Panse R, Berrih-Aknin S (2020) Comparative analysis of thymic and blood Treg in myasthenia gravis: thymic epithelial cells contribute to thymic immunoregulatory defects. Front Immunol 11:782. https://doi.org/10.3389/fimmu.2020. 00782

208. Cordiglieri C, Marolda R, Franzi S, Cappelletti C, Giardina C, Motta T, Baggi F, Bernasconi P, Mantegazza R, Cavalcante P (2014) Innate immunity in myasthenia gravis thymus: pathogenic effects of Toll-like receptor 4 signaling on autoimmunity. J Autoimmun 52:74-89. https://doi.org/10.1016/j.jaut.2013.12.013

209. Fujii Y, Monden Y, Hashimoto J, Nakahara K, Kawashima Y (1985) Acetylcholine receptor antibody-producing cells in thymus and lymph nodes in myasthenia gravis. Clin Immunol Immunopathol 34(1):141-146. https://doi.org/10.1016/00901229(85)90018-2

210. Strobel P, Hartmann E, Rosenwald A, Kalla J, Ott G, Friedel G, Schalke B, Kasahara M, Tomaru U, Marx A (2014) Corticomedullary differentiation and maturational arrest in thymomas. Histopathology 64(4):557-566. https://doi.org/10. 1111/his.12279

211. Willcox N, Schluep M, Ritter MA, Schuurman HJ, NewsomDavis J, Christensson B (1987) Myasthenic and nonmyasthenic thymoma. An expansion of a minor cortical epithelial cell subset? Am J Pathol 127(3):447-460

212. Buckley C, Douek D, Newsom-Davis J, Vincent A, Willcox N (2001) Mature, long-lived CD4+ and CD8+ T cells are generated by the thymoma in myasthenia gravis. Ann Neurol 50(1):64-72

213. Nitta H, Mihara K, Sakai A, Kimura A (2010) Expansion of CD8+ /perforin+ effector memory T cells in the bone marrow of patients with thymoma-associated pure red cell aplasia. Br J Haematol 150(6):712-715. https://doi.org/10.1111/j.1365-2141.2010. 08273.x

214. Radovich M, Pickering CR, Felau I, Ha G, Zhang H, Jo H, Hoadley KA, Anur P, Zhang J, McLellan M, Bowlby R, Matthew T, Danilova L, Hegde AM, Kim J, Leiserson MDM, Sethi G, Lu C, Ryan M, Su X, Cherniack AD, Robertson G, Akbani R, Spellman P, Weinstein JN, Hayes DN, Raphael B, Lichtenberg T, Leraas K, Zenklusen JC, Fujimoto J, Scapulatempo-Neto C, Moreira AL, Hwang D, Huang J, Marino M, Korst R, Giaccone G, Gokmen-Polar Y, Badve S, Rajan A, Strobel P, Girard N, Tsao MS, Marx A, Tsao AS, Loehrer PJ (2018) The integrated genomic landscape of thymic epithelial tumors. Cancer Cell 33(2):244-258.e210. https://doi.org/10.1016/j. ccell.2018.01.003

215. Strobel P, Murumagi A, Klein R, Luster M, Lahti M, Krohn K, Schalke B, Nix W, Gold R, Rieckmann P, Toyka K, Burek C, Rosenwald A, Muller-Hermelink HK, Pujoll-Borrell R, Meager A, Willcox N, Peterson P, Marx A (2007) Deficiency of the autoimmune regulator AIRE in thymomas is insufficient to elicit autoimmune polyendocrinopathy syndrome type 1 (APS-1). J Pathol 211(5):563-571. https://doi.org/10.1002/path.2141

216. Kisand K, Lilic D, Casanova JL, Peterson P, Meager A, Willcox N (2011) Mucocutaneous candidiasis and autoimmunity against cytokines in APECED and thymoma patients: clinical and pathogenetic implications. Eur J Immunol 41(6):1517-1527. https://doi. org/10.1002/eji.201041253

217. Strobel P, Helmreich M, Menioudakis G, Lewin SR, Rudiger T, Bauer A, Hoffacker V, Gold R, Nix W, Schalke B, Elert O, Semik M, Muller-Hermelink HK, Marx A (2002) Paraneoplastic myasthenia gravis correlates with generation of mature naive $\mathrm{CD} 4(+) \mathrm{T}$ cells in thymomas. Blood 100(1):159-166

218. Hoffacker V, Schultz A, Tiesinga JJ, Gold R, Schalke B, Nix W, Kiefer R, Muller-Hermelink HK, Marx A (2000) Thymomas alter the T-cell subset composition in the blood: a potential mechanism for thymoma-associated autoimmune disease. Blood 96(12): 3872-3879

219. Ströbel P, Preisshofen T, Helmreich M, Müller-Hermelink HK, Marx A (2003) Pathomechanisms of paraneoplastic myasthenia gravis. Clin Dev Immunol 10(1):7-12. https://doi.org/10.1080/ 10446670310001598528

220. Nagvekar N, Moody AM, Moss P, Roxanis I, Curnow J, Beeson D, Pantic N, Newsom-Davis J, Vincent A, Willcox N (1998) A pathogenetic role for the thymoma in myasthenia gravis. Autosensitization of IL-4- producing T cell clones recognizing extracellular acetylcholine receptor epitopes presented by minority class II isotypes. J Clin Invest 101(10):2268-2277. https://doi.org/ 10.1172/jci2068

221. Shiono H, Wong YL, Matthews I, Liu JL, Zhang W, Sims G, Meager A, Beeson D, Vincent A, Willcox N (2003) Spontaneous production of anti-IFN-alpha and anti-IL-12 autoantibodies by thymoma cells from myasthenia gravis patients suggests autoimmunization in the tumor. Int Immunol 15(8):903913. https://doi.org/10.1093/intimm/dxg088

222. Liu Y, Zhang H, Zhang P, Meng F, Chen Y, Wang Y, Yao Y, Qi B (2014) Autoimmune regulator expression in thymomas with or without autoimmune disease. Immunol Lett 161(1):50-56. https://doi.org/10.1016/j.imlet.2014.04.008

223. Ramsey C, Hässler S, Marits P, Kämpe O, Surh CD, Peltonen L, Winqvist $O$ (2006) Increased antigen presenting cell-mediated T cell activation in mice and patients without the autoimmune regulator. Eur J Immunol 36(2):305-317. https://doi.org/10.1002/eji. 200535240

224. Ströbel P, Chuang WY, Chuvpilo S, Zettl A, Katzenberger T, Kalbacher H, Rieckmann P, Nix W, Schalke B, Gold R, MüllerHermelink HK, Peterson P, Marx A (2008) Common cellular and 
diverse genetic basis of thymoma-associated myasthenia gravis: role of MHC class II and AIRE genes and genetic polymorphisms. Ann N Y Acad Sci 1132:143-156. https://doi.org/10.1196/annals. 1405.018

225. Strobel P, Rosenwald A, Beyersdorf N, Kerkau T, Elert O, Murumagi A, Sillanpaa N, Peterson P, Hummel V, Rieckmann P, Burek C, Schalke B, Nix W, Kiefer R, Muller-Hermelink HK, Marx A (2004) Selective loss of regulatory T cells in thymomas. Ann Neurol 56(6):901-904. https://doi.org/10.1002/ana.20340

226. Zettl A, Ströbel P, Wagner K, Katzenberger T, Ott G, Rosenwald A, Peters K, Krein A, Semik M, Müller-Hermelink HK, Marx A (2000) Recurrent genetic aberrations in thymoma and thymic carcinoma. Am J Pathol 157(1):257-266. https://doi.org/10.1016/ s0002-9440(10)64536-1
227. Marx A, Willcox N, Leite MI, Chuang WY, Schalke B, Nix W, Strobel P (2010) Thymoma and paraneoplastic myasthenia gravis. Autoimmunity 43(5-6):413-427. https://doi.org/10.3109/ 08916930903555935

228. Zhao C, Rajan A (2019) Immune checkpoint inhibitors for treatment of thymic epithelial tumors: how to maximize benefit and optimize risk? Mediastinum (Hong Kong, China) 3:35. https://doi. org/10.21037/med.2019.08.02

Publisher's Note Springer Nature remains neutral with regard to jurisdictional claims in published maps and institutional affiliations. 